DUMPING SITES IN THE LJUBLJANSKO POLJE WATER PROTECTION AREA, THE PRIMARY SOURCE OF LJUBLJANA'S DRINKING WATER ODLAGALIŠČA ODPADKOV NA
VODOVARSTVENEM OBMOČJU LJUBLJANSKEGA POLJA, GLAVNEM VIRU OSKRBE LJUBLJANE S PITNO VODO

Mateja Breg, Drago Kladnik, Aleš Smrekar

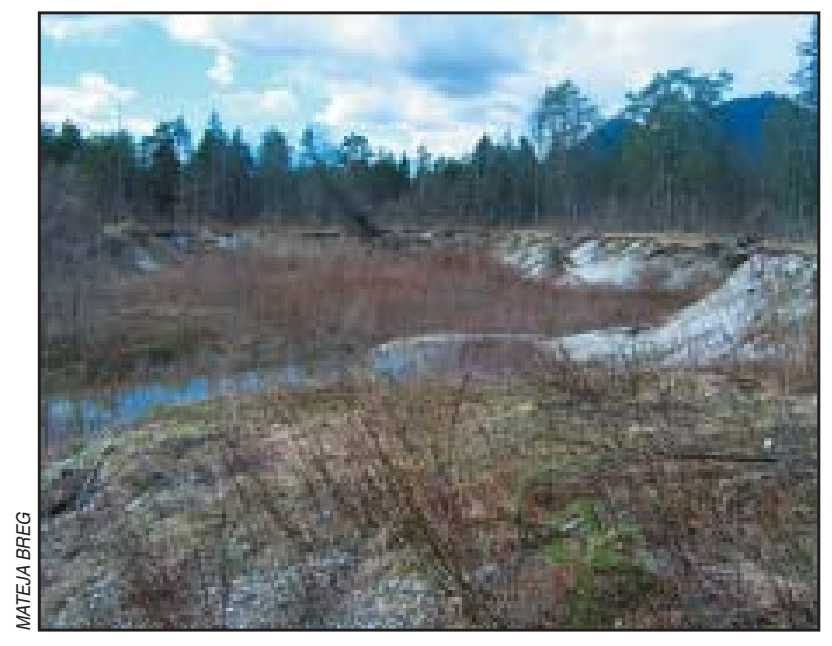

Underground water is most threatened by illegal dumping sites in gravel pits. Podzemno vodo najbolj ogrožajo divja odlagališča v gramoznicah.

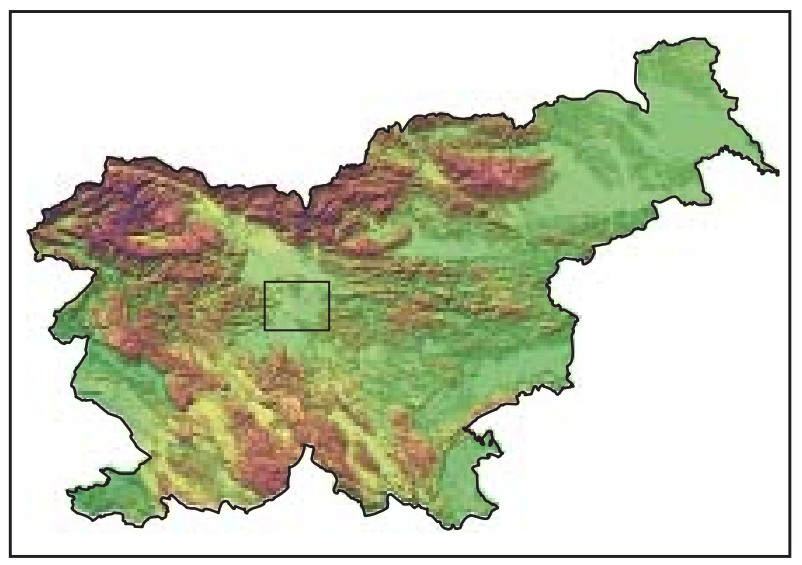




\title{
Dumping sites in the Ljubljansko polje water protection area, the primary source of Ljubljana's drinking water
}

\author{
UDC: 911.3:628.472.2(497.4Ljubljansko polje) \\ 628.472.2:504.5(497.4Ljubljansko polje)
}

COBISS: 1.01

ABSTRACT: Ljubljansko polje is a gravel plain lying along the Sava River north of Ljubljana. Although
built-up areas are steadily expanding, the water protection area has helped preserve the character of rel-
atively intensely cultivated agricultural land at least in its central part. However, illegal dumping sites pose
a threat to the groundwater in the gravel aquifer. In the narrowest and narrow water protection areas of
Ljubljansko polje, we have found, registered, and studied 1,445 illegal dumping sites with a total surface
area amounting to $120,816 \mathrm{~m}^{2}$ and a total volume of $209,422 \mathrm{~m}^{3}$. A good seventh $(13.5 \%)$ of the total waste
is hazardous. In the area surveyed, we also registered 86 gravel pits, 47 information and warning signs,
and 57 road barriers on access roads. In time, it will be necessary to rehabilitate all the illegal dumping
sites; however, due to the large quantity of waste it is unrealistic to expect this to happen in one go, and
we have therefore established a priority schedule for the rehabilitation.

KEYWORDS: geography, environmental protection, illegal dumping site, water protection area, Ljubljana, groundwater, rehabilitation

The article was submitted for publication on February 28, 2007.

\section{ADDRESSES:}

\section{Mateja Breg, B.Sc.}

Anton Melik Geographical Institute

Scientific Research Center of the Slovenian Academy of Sciences and Arts

Gosposka ulica 13, SI - 1000 Ljubljana, Slovenia

E-mail:mateja.breg@zrc-sazu.si

\section{Drago Kladnik, Ph. D.}

Anton Melik Geographical Institute

Scientific Research Center of the Slovenian Academy of Sciences and Arts

Gosposka ulica 13, SI - 1000 Ljubljana, Slovenia

E-mail: drago.kladnik@zrc-sazu.si

\author{
Aleš Smrekar, Ph. D. \\ Anton Melik Geographical Institute \\ Scientific Research Center of the Slovenian Academy of Sciences and Arts \\ Gosposka ulica 13, SI - 1000 Ljubljana, Slovenia \\ E-mail: ales.smrekar@zrc-sazu.si
}

\section{Contents}

$\begin{array}{lll}1 & \text { Introduction } & 75 \\ 2 & \text { Outline of studied area } & 75 \\ 3 & \text { Legislative provisions } & 77 \\ 4 & \text { Work methods } & 78 \\ 5 & \text { Basic features of illegal dumping sites } & 80 \\ 5.1 & \text { Size parameters of illegal dumping sites } & 80 \\ 5.2 & \text { Composition of waste } & 82 \\ 5.3 & \text { Environmental parameters of dumping sites } & 84 \\ 6 & \text { Priority rehabilitation of dumping sites } & 88 \\ 7 & \text { Conclusions } & 88 \\ 8 & \text { References } & 91\end{array}$




\section{Introduction}

On one hand, in the irregular relief of Slovenia, gravel plains with aquifers are the most important source of drinking water, supplying water to more than $90 \%$ of the population, and on the other, they comprise the economic, traffic, and settling core of the country (Kladnik et al. 2002). In the last few decades, these areas have been distinctly subject to urban activities that have almost supplanted agriculture, which relative to surface area still remains its biggest user. In spite of numerous restrictions in the water protection areas, the cities have expanded onto these areas as well, especially on the areas of zones with less strict protection regimes (Bračič Železnik et al. 2005; Rejec Brancelj 2001), which we can now consider urban areas.

Modern cities in economically developed countries deviate substantially from the concepts of sustainable development because their activities and populations need very extensive areas of agriculturally productive land to meet their material and energy demands and for dumping various emissions and wastes (Hille 1994, Hille 1997; cited in Plut 2003). The degradation of the urban landscape originates in the incompleteness of the material circles (e.g. waste) and the use of non-renewable energy resources (e.g. gravel), which results in burdening of the landscape and changes in landscape structure and the dynamics of cities and their surroundings (Breg, Urbanc 2005; Urbanc, Breg 2005).

The land on riverine gravel plains in many places is out of sight and therefore has always been exposed to illegal encroachments by the urban population, resulting in ever increasing degradation. In many cases, the riverine landscape has not found its proper place in the value system of the population, who consider it only as a natural resource and a place for illegal encroachments. Gravel pits and illegal dumping sites are a good example. The number of illegal dumping sites and their negative impact are greater than we are willing to admit to ourselves, which reduces the possibilities for the rapid and comprehensive regulation of the problem. In Slovenia, such dumping sites are a relatively new, undesirable, and disturbing part of the landscape.

Due to the various negative impacts of illegal dumping sites, the authorities are trying to systematically prevent the occurrence of new illegal dumping sites and the accumulation of additional waste on already existing illegal dumping sites. The fundamental principles of waste management are:

- solving the waste problem at the source (reduction of volume),

- prevention,

- separate collection of waste material,

- recycling of organic waste,

- rational and gradual establishment of a network of facilities for waste management,

- rational use of space,

- protection of natural and cultural values, and

- rehabilitation of illegal dumping sites.

One of the main measures for the promotion of long-term principles of waste managing is education, training, and providing information. Public opposition to appropriate waste management appears particularly on the local, implementation level, while individuals in the wider community have a more positive attitude. However, waste is a reality and we must face its negative impacts and solve them as effectively as possible.

\section{Outline of studied area}

The quantity of groundwater contained in the aquiferous gravel-sand and conglomerate layers that fill the Ljubljansko polje depression is estimated at up to 100 million $\mathrm{m}^{3}$. This is one of the largest reservoirs of undergorund water in Slovenia, a natural resource of regional importance (Bračič Železnik et al. 2005a). The depth to the groundwater depends on its water table and the altitude of the terrain. On a high terrace near Vižmarje, the groundwater is found at a depth of more than thirty meters, and between Ježica and Zadobrova, at depths of only five to ten meters. The annual regime of water table changes in the 1987-2005 period indicates considerable annual oscillation. In the Brod area, the oscillation spans 4 to 6 meters, around the Kleče pumping station 5 to 6 meters, and around the Hrastje pumping station 1.5 to 2 meters.

In general, the groundwater flows from the northwest to the southeast or east. In the western part of the aquifer, its velocity is between 5 and 10 meters per day, and in the eastern part, mostly between 10 and 20 meters per day (Auersperger et al. 2005). 
Mateja Breg, Drago Kladnik, Aleš Smrekar, Dumping sites in the Ljubljansko polje water protection area, the primary source ...

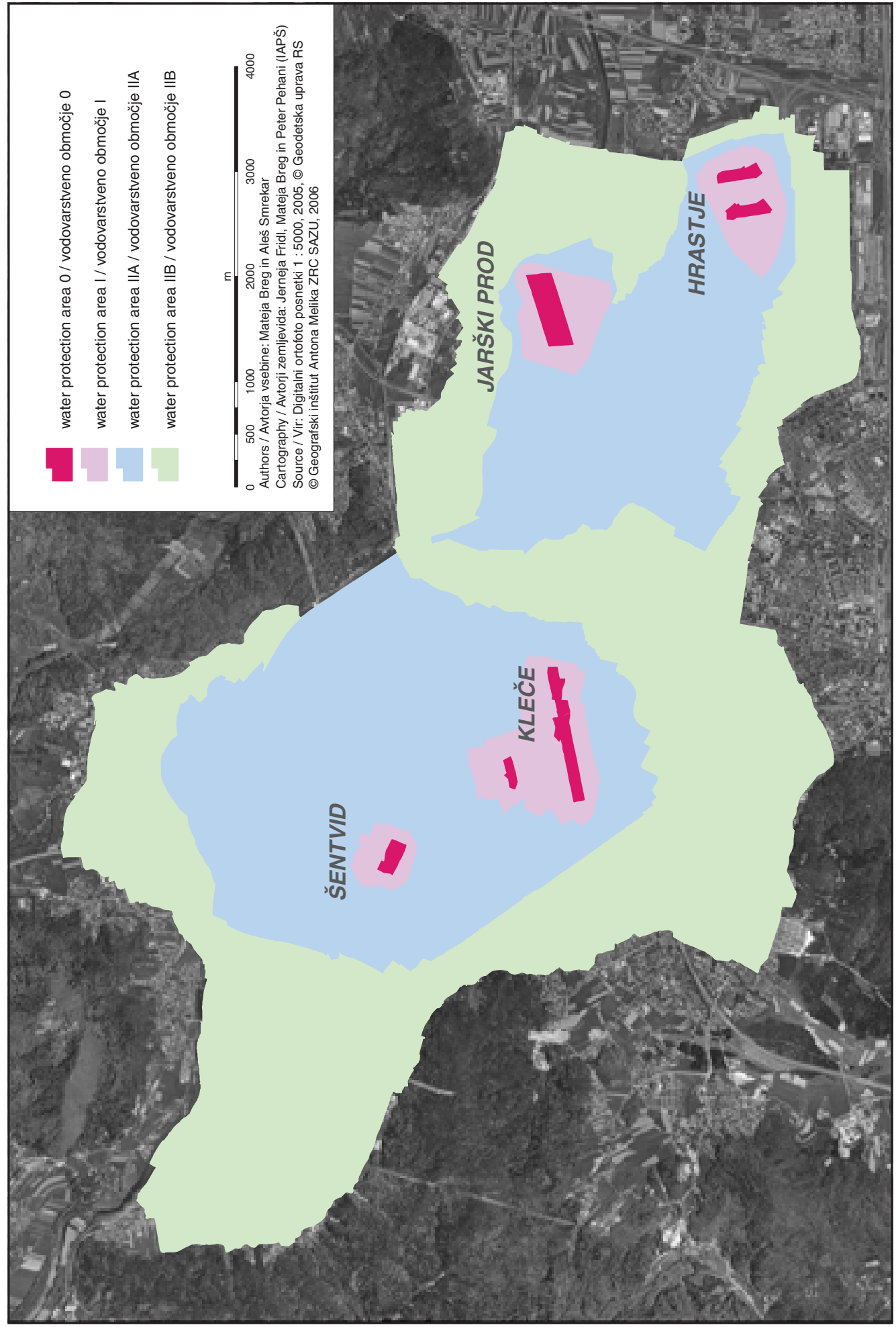


Figure 1: The narrowest and narrow water protection areas on Ljubljansko polje.

The primary source for the charging of the Ljubljansko polje aquifer is the Sava River, and the secondary source is the infiltration of precipitation water, which in places is considerably reduced due to urban land use (Smrekar 2004). In its upper part, the Sava charges the aquifer while in its lower part, the groundwater flows back into the river (Auersperger et al. 2005). The second largest surface watercourse on Ljubljansko polje is the Ljubljanica River. However, its flow is slow and its silty bottom greatly limits the transfer of water between the river and the aquifer.

The City Municipality of Ljubljana supplies its population and industry from a number of water sources. The most extensive pumping sites of drinking water for the supply of Ljubljana are situated on Ljubljansko polje, and its pumping stations are incorporated in the central water system. According to the Decree on the Water Protection Zone for the Aquifer of Ljubljansko polje (Official Gazette of the RS No. 120/2004), an area of $42.98 \mathrm{~km}^{2}$ lies within the narrowest $(0, \mathrm{I})$ and narrow (IIA, IIB) water protection areas.

Water started to flow in the first 606 of Ljubljana's houses on May 17, 1890, and the Kleče pumping station remains the heart of Ljubljana's water system. The Hrastje pumping station was opened in 1953, the Šentvid pumping station in 1955, and the Jarški prod pumping station in 1982 (Bračič Železnik, Jamnik 2005).

Underground water is closely connected with natural conditions and human activities. Its vulnerability depends on the hydrogeological, hydrological, and pedological conditions. Various construction works and excavations such as the excavation of gravel also have an impact on it. There are illegal gravel pits outside the consolidated urban area, especially on the lower terraces beside the Sava River.

Four large legal gravel pits are located in Stanežiče, in the Dovjež area, southwest of the expressway intersection in Tomačevo, and in Obrije. They are all in the rehabilitation phase. Fortunately, the abandoned gravel pits were not filled with large quantities of waste since after 1924 when organized waste collection started, waste was transported mainly to southern parts of Ljubljana (Orožen Adamič, Pleskovič 1975).

The cleansing capability of gravel and sand cover layers is effective with biological contamination but less so with chemical contamination. In general, the concentration of contaminatants decreases with the distance they travel through the ground. Soluble wastes, including fertilizers and certain industrial waste materials, cannot be removed by filtration, and metallic solutions are not susceptible to biological processes.

We can conclude from the analysis of changing land use (Frantar et al. 2005) that urbanization is the most important cause of groundwater pollution. Urbanization has caused the amount of farm land to shrink, although agricultural land use has increasingly spread closer to the Sava River (Kladnik et al. 2004). Allotment gardeners, as a group with a large number of users of agricultural land, are having an increasing impact with their unique cultivation and other activities.

\section{Legislative provisions}

For a long time, standard-setting regulation of waste management has been one of the most problematic fields of environmental protection in Slovenia. The main reasons are the previous social indifference to waste and waste management, the lack of vertical and horizontal administrative and professional coordination and organization, economic measures, and the natural characteristics of the Slovene environment (Viler Kovačič 2001).

Before the implementation of the Environmental Protection Act in 1993, the entire system of waste management was regulated by the Waste Management Act (OG SRS 8/1978). It introduced the commitment that the creation of waste should be prevented and limited, that the waste should be recycled, and that waste should be managed in a wise, safe, and environmentally friendly fashion.

The implementation of the Environmental Protection Act (OG RS 32/1993 with amendments) introduced a new approach to solving environmental protection issues in general, including the solution of the waste management problem, which had become ever more pressing. The amended Environmental Protection Act (OG RS 41/2004 with amendments) follows similar guidelines.

Increased progress in the standard-setting regulation of waste management actually only began in 1998 with the adoption of the Regulations for the Management of Waste (OG RS 84/1998 with amendments) as the basis for waste management. These regulations are also called the "general regulations on waste" since they define obligatory ways of waste management and other conditions for the collection, transportation, 
processing, and removal of waste. It is also important because it introduced the European classification list of all types of waste, among which hazardous waste is specially defined. The regulations emphasize that collection, storage, transportation, processing, and removal of waste must be done in a manner that does not present a threat to human health and without the use of procedures and methods that would present an excess burden on the environment.

Since 2000, the obligatory waste management and other conditions for its disposal and dumping site activities have been defined by the Regulations on the Landfill of Waste (OG RS 5/2000 with amendments), which was followed in 2006 by the Decree on the Landfill of Waste (OG RS 32/2006) that specifically emphasized that waste must only be dumped at authorized dumping sites. Thus it is forbidden to dump waste in places and areas that are not defined as authorized dumping sites. The Decree also states that dumping sites are not permitted in water protection areas.

The Regulation on Soil Pollution Caused by Waste Deposits (OG RS 3/2003) defines obligatory actions in the planning and implementation of excavations or artificial landfill for the improvement of the ecological condition of the ground, which is important for the rehabilitation of gravel pits whether empty or filled with waste.

Given that waste management falls under competence of the Ministry for the Environment and Spatial Planning, the greatest authority is given to the Inspectorate of the Republic of Slovenia for the Environment and Spatial Planning, a body of this ministry. Certain regulations in this field are also monitored by the market, health, and veterinary inspectors and inspectors for nuclear safety and energy production as well as by city inspectors.

Water protection is regulated and directed by the Framework Directive on Water adopted in 2000 by the European Parliament and the EU Council of Ministers. It is based on comprehensive and sustainable water management, where the quantity and the quality of different types of water, including underground water, are equally important (Lanz, Scheuer 2001). The umbrella law in the field of water in Slovenia is the Waters Act (OG RS 67/2002), which is of course in line with the European directive.

Drinking water protection zones or water protection areas, as they are more recently labelled, have a long tradition on Ljubljansko polje. First designated in 1955, they were decisive for the protection of the water source because they limited the spread of the city in the vicinity of water pumping stations (Breznik 1988). In 1977 and 1988, they were followed by two updated decrees. The latest Decree on the Water Protection Zone for the Aquifer of Ljubljansko polje (UL RS 120/2004) is based on extensive research work. This is the first decree originating in the Regulations on Criteria for the Designation of a Water Protection Zone (OG RS 64/2004).

The terms and methods for the supply of Ljubljana with drinking water are regulated by the Decree on the Supply of Drinking Water (OG RS 17/2006). The Regulations on Drinking Water (OG RS 19/2004 with amendments) specify requirements for the uniformity and health suitability of drinking water and prescribe conditions for ensuring healthy drinking water. The Decree on Quality Standards for Groundwater (UL RS 100/2005) states the standards for determining its chemical condition, for the evaluation of long-term trends of its contamination and their changes, the state of the pollution of the water body, when measures for the prevention and limitation of the input of contaminants into the groundwater should begin, and for determining when to stop rehabilitation activities.

\section{Work methods}

An inventory of illegal dumping sites, an analysis of their condition, and the preparation of proposals for their rehabilitation was undertaken from March to September 2006 in several work phases (Smrekar et al. 2006): - preparation work: analysis of literature and secondary sources, examination of legislative instruments, collection of accessible existing databases;

- field work: mapping and survey of illegal dumping sites, data acquisition using PDA's;

- computer processing of data: data entry and organization of spatial data in databases, statistical processing, spatial analyses;

- chemical analysis of samples: preparation and analysis of representative samples;

- graphical presentation: presentation of the results of actual situation on maps and graphs

- rehabilitation program: proposal of most urgent rehabilitation interventions. 


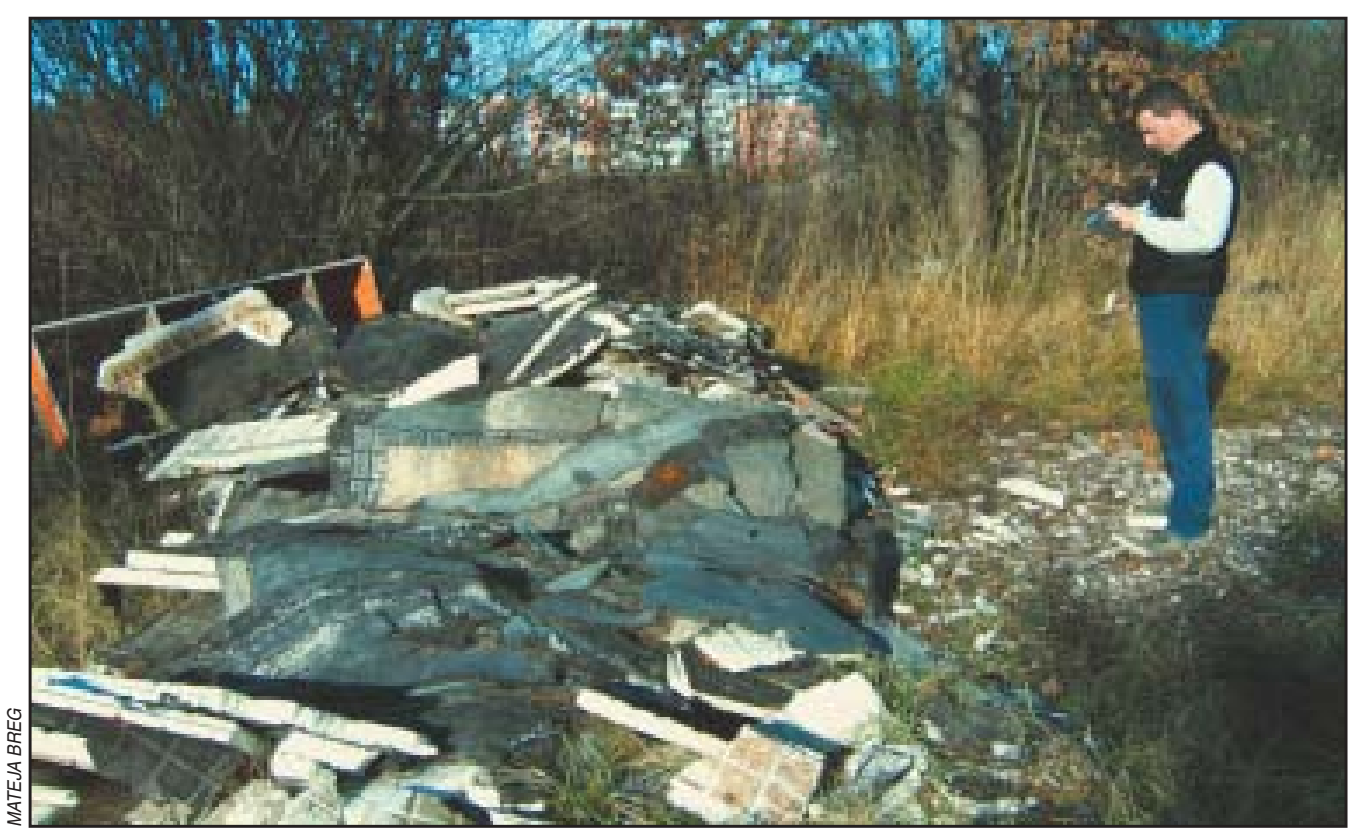

Figure 2: Field inventory of illegal dumping sites.

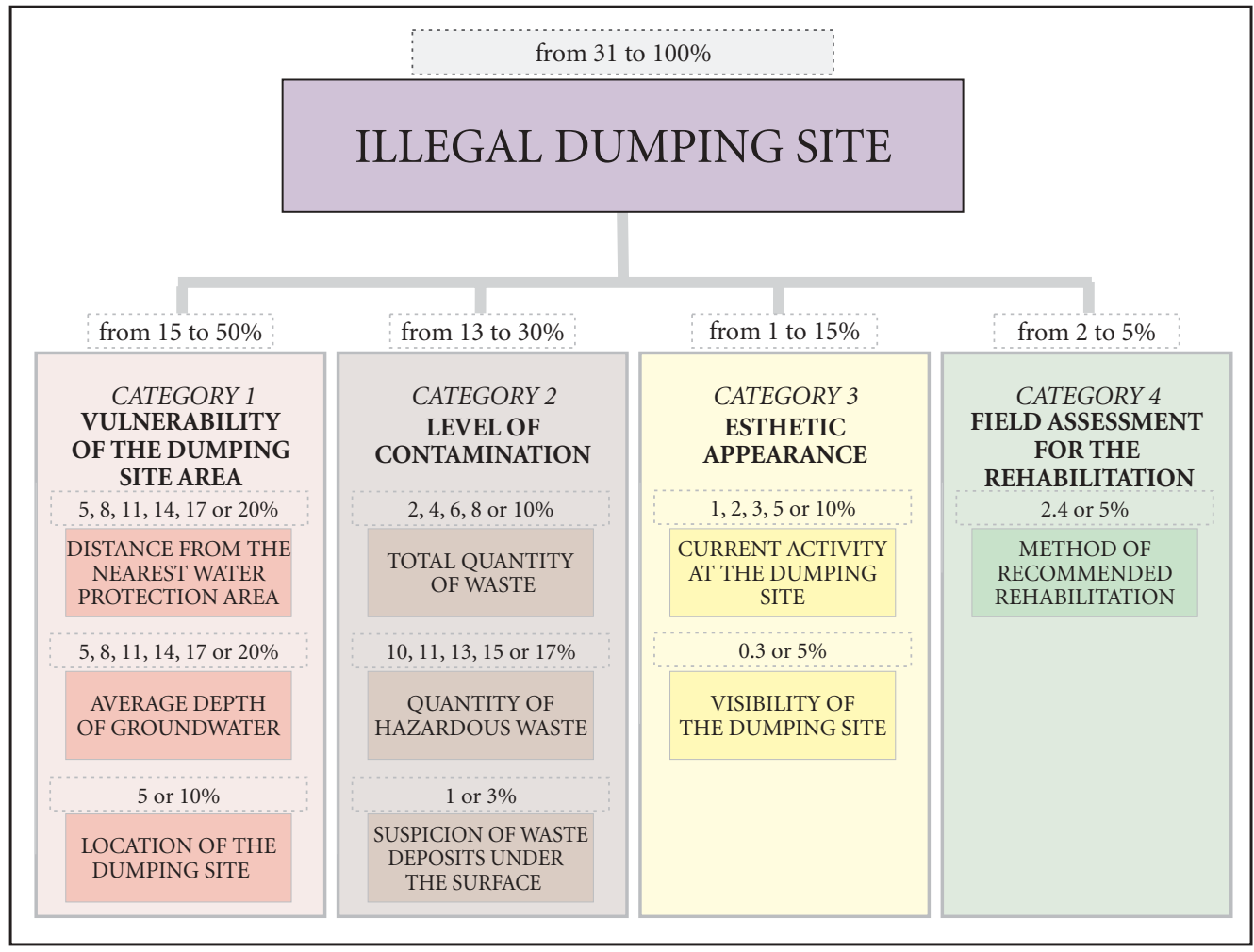

Figure 3: Classification and evaluation of indicators for establishing priority rehabilitation of illegal dumping sites. 
Establishing priority for the rehabilitation of illegal dumping sites was done on the basis of indicators of key importance from the viewpoint of environmental issues (Breg et al. 2005). We considered the landscape and ecological characteristics of the area from the viewpoint of the contamination of the water source and several surveyed characteristics of the dumping sites. We combined the selected indicators into four categories according to their assumed significance from the viewpoint of establishing priority rehabilitation and determined appropriate weights for each.

The Slovene version of this article uses the term »divje odlagališče odpadkov« for »illegal dumping sites, « but other synonymous terms such as »nedovoljen odlagališče odpadkov, « »neurejen odlagališče odpadkov, « črno odlagališče odpadkov,» and "nelegalno odlagališče odpadkov» also exist in the literature (Kladnik et al. 2005).

\section{Basic features of illegal dumping sites}

Previous cadastres of dumping sites exist. In September 1996, the Oikos company surveyed the entire area of the City Municipality of Ljubljana (Kobal et al. 1996) and registered 457 dumping sites with a total volume of $32,782 \mathrm{~m}^{3}$. The Bion company also performed a study at the level of the entire municipality (Berden et al. 2004), in which the data was processed according to district communities. The study registered 278 illegal dumping sites with an estimated total volume of $100,000 \mathrm{~m}^{3}$. In both studies, the border value for a registered dumping site was one cubic meter of waste. It is interesting and curious that according to the cited data the number of dumping sites supposedly decreased by almost 40\% between 1996 and 2004 while the quantity of waste supposedly increased by more than three times.

The first thorough study of illegal dumping sites in Slovenia was performed a good decade ago (Šebenik 1994). Compared with earlier studies, an important innovation in Šebenik's approach was the quite accurate treatment of the volume parameters of the dumping sites. Šebenik analyzed 3,501 sample dumping sites with volumes from one cubic meter to $10,000 \mathrm{~m}^{3}$. The average dumping site measured $135 \mathrm{~m}^{2}$ and contained $47 \mathrm{~m}^{3}$ of waste material. Dumping sites with volumes up to $1,000 \mathrm{~m}^{3}$ contained $39 \%$ of the waste, indicating that smaller dumping sites are important from the viewpoint of the quantity of waste material and not just for their number.

We found, registered, and studied 1,445 illegal dumping sites in the studied area on Ljubljansko polje with a total surface area of $120,816 \mathrm{~m}^{2}$, which means that waste covers $0.28 \%$ of the entire area and makes this one of the most waste-polluted areas in Slovenia. The total volume of waste is $209,422 \mathrm{~m}^{3}$. The average dumping site measures $83.6 \mathrm{~m}^{2}$ and contains $145.5 \mathrm{~m}^{3}$ of waste material. We also registered $86 \mathrm{dung}$ pits, 47 information and warning signs, and 57 road barriers on access roads.

At the request of the inspection authorities, the Snaga company, which is responsible for the disposal of communal waste in Ljubljana, has removed a total of $36,499 \mathrm{~m}^{3}$ of communal waste from all the illegal dumping sites in the City Municipality of Ljubljana in the last six years (2000-2005).

\subsection{Size parameters of illegal dumping sites}

Among the 1,445 surveyed illegal dumping sites, small dumping sites dominate. Some 550 or a good third of the dumping sites do not exceed $10 \mathrm{~m}^{2}$, and most (696 or $48.1 \%$ ) are in the $11 \mathrm{~m}^{2}$ to $100 \mathrm{~m}^{2}$ size class. Only 199 dumping sites measure more than $100 \mathrm{~m}^{2}$, and while only 24 dumping sites exceed $1,000 \mathrm{~m}^{2}$, all together they occupy $7.3 \%$ of the total surface area of dumping sites. The surface area of the largest dumping site is estimated to be $6,000 \mathrm{~m}^{2}$.

As the surface area covered by the dumping sites increases, their thickness also typically increases. Although the thickness of 802 dumping sites does not exceed one meter deep (360 dumping sites do not exceed $0.5 \mathrm{~m}$ ), the waste on more than one hundred dumping sites has accumulated to at least two meters thick, and the thickest dumping site in one of the abandoned gravel pits reaches a depth of 11 meters.

Some 757 or more than half $(52.4 \%)$ of the dumping sites do not exceed a volume of $10 \mathrm{~m}^{3}$, but in spite of their number they contain only a small percentage $(1.3 \%)$ of the total quantity of identified waste. On the other hand, there are 36 dumping sites with a volume of $1,000 \mathrm{~m}^{3}$ and more where almost three 


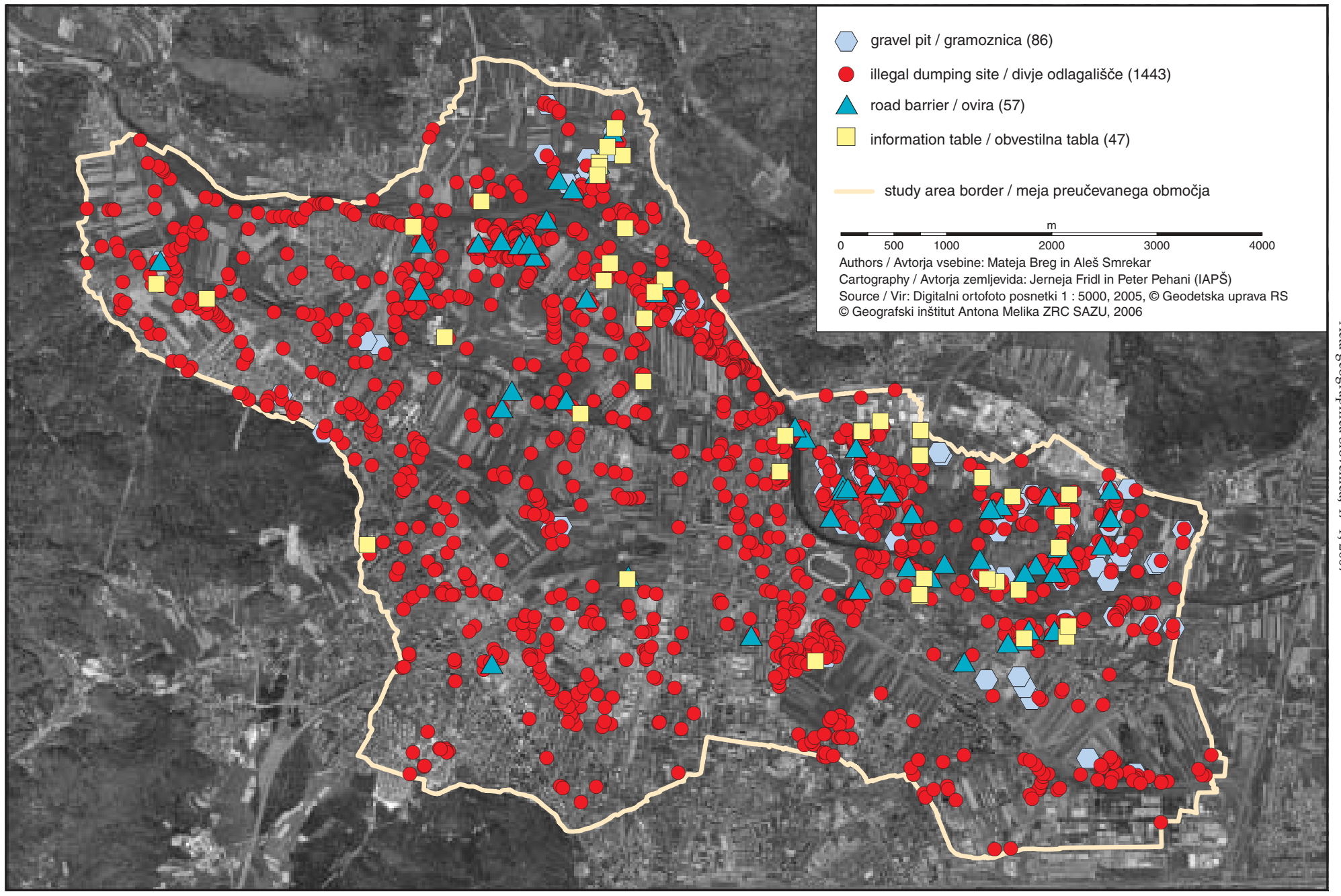


Figure 5: Illegal dumping sites according to land ownership.

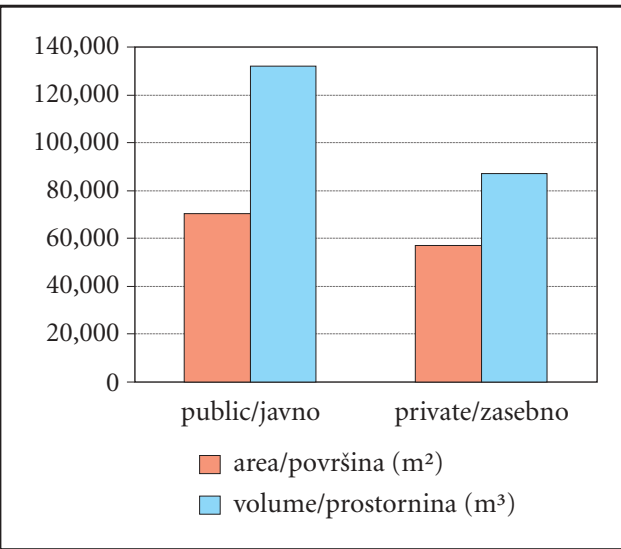

quarters $(72.5 \%)$ of the waste is accumulated. The largest dumping site contains about $42,000 \mathrm{~m}^{3}$ or almost a fifth of the identified waste.

While much of the waste is found on privately-owned land, well over half is found on "public asset« category land or land owned by companies. The latter land covers $54.0 \%$ of the surface area and accounts for $61.3 \%$ of the volume of the registered waste. This reveals a lack of supervision of the public sector land, although the private owners are also obviously helpless against illegal dumping. Some $16.5 \%$ of the illegal dumping sites are on municipality land and account for more than a quarter $(25.8 \%)$ of all such occupied surfaces and more than one third $(37.8 \%)$ of the total quantity of recorded waste.

\subsection{Composition of waste}

Illegally dumped waste is rarely homogenous. In most cases, it is a mix of waste of local origin (construction, industrial, communal, primary sector waste, tailings). The location of dumping sites is often detrimental from the viewpoint of both groundwater contamination and their unsightly appearance, which has an impact on the quality of the living environment and the tourist and recreational attractiveness of the landscape.

In our research, we classified waste into the following groups:

- primary sector waste;

- industrial waste;

- construction waste;

- medical and veterinary waste;

- communal waste;

- other waste.

A more detailed classification according to the types of waste revealed that two thirds $(67.3 \%)$ of the waste comes from construction operations (demolition waste material, surplus dirt from the excavation of new building sites), followed by waste from the primary sector $(17.8 \%)$. Communal waste comprises $10.2 \%$, industrial waste $1.4 \%$, and medical and veterinary waste $1.1 \%$.

In general, the impact of construction waste material on the environment is negligible, but only if the wastes do not contain elements that could chemically contaminate the environment. Common household waste usually contains hazardous chemical substances such as motor oil, detergents, sprays, and the like (Šebenik 1994). To prevent the dangerous contamination of groundwater, these wastes must have priority in the envisaged rehabilitation of dumping sites.

Hazardous waste is composed mostly of abandoned vehicles, barrels with unknown contents (empty metal barrels are classified as bulky waste), and containers for paints, lacquers, motor oil, and agrochemical substances. Communal waste is mostly solid, composed of heterogeneous household and similar wastes 


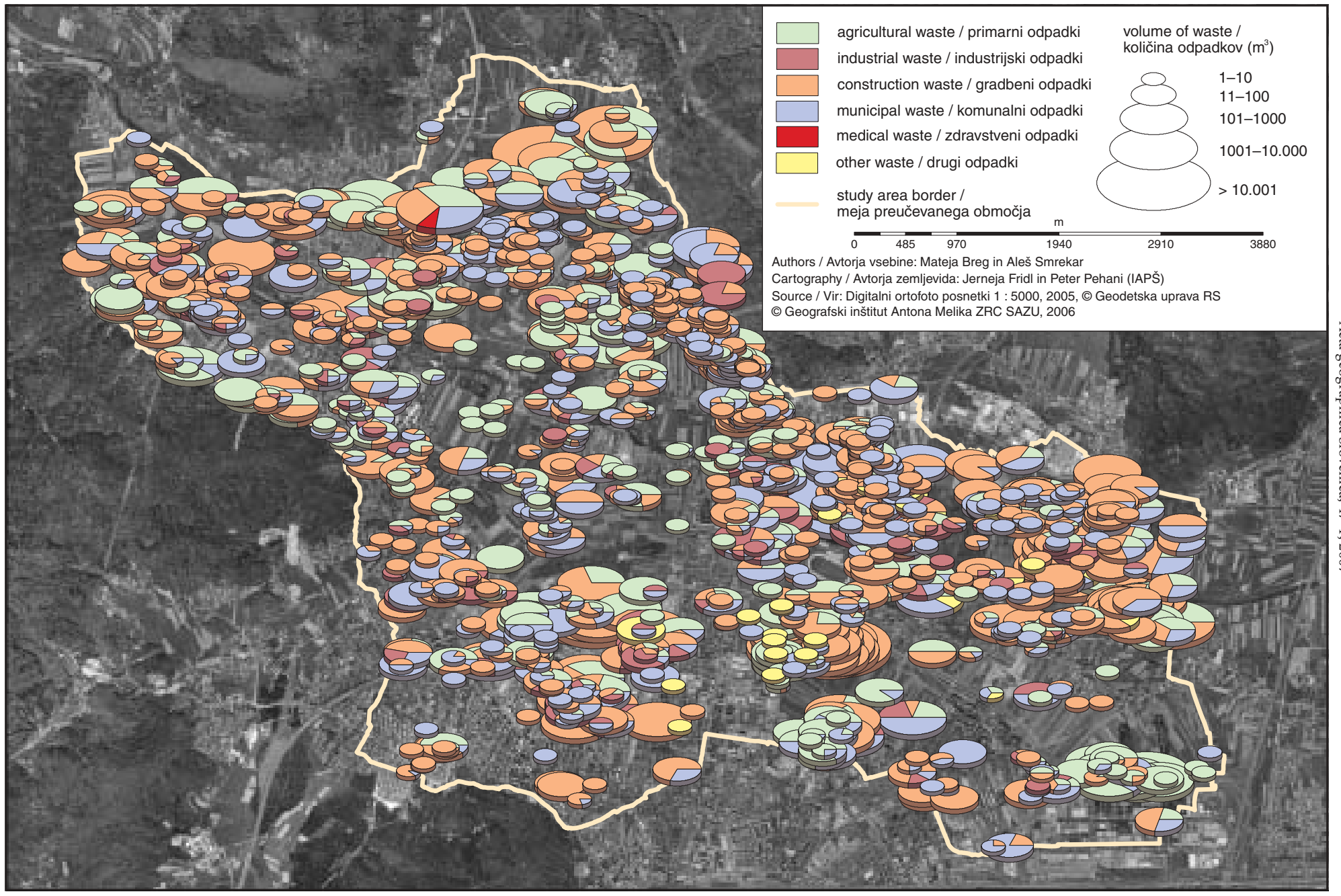


generated by production and service activities in the living environment and in areas and buildings in public use. Due to its diverse and variable composition, it is technologically difficult to separate communal waste into its components. The quantity of communal waste found at illegal dumping sites is somewhat surprising since according to the data from the Snaga company, $99 \%$ of the households in Ljubljana have organized waste collection.

The volume of hazardous waste is $28,749 \mathrm{~m}^{3}, 13.7 \%$ of the total volume. The main hazardous construction wastes include asbestos panels, asphalt, impregnated glass wool, tar paper, and unemptied containers. Hazardous industrial waste includes parts of machinery and equipment, the remains of refrigerators, industrial adhesives, paint and solvent containers, paint in plastic bottles, motor oil, and various types of metal barrels with unknown contents. Hazardous communal waste includes the remains of household appliances and other appliances containing parts with environmentally-hazardous substances.

\subsection{Environmental parameters of dumping sites}

Waste is scattered everywhere except in the fenced catchment areas (water protection area 0 ). The largest number of dumping sites ( 760 or $52.6 \%$ of all sites with a total surface area of $57,340 \mathrm{~m}^{2}$ or $47.5 \%$, and a volume of $118,975 \mathrm{~m}^{3}$ or $56.8 \%$ ) are located in the narrow areas with a strict water protection regime (IIA). Of course, dumping sites located closer to the pumping stations (water protection area I) are potentially more hazardous, but the quantity of waste here is substantially smaller. Fortunately, there are only 71 such dumping sites with a total area of $8,589 \mathrm{~m}^{2}(7.2 \%)$ and a volume of $10,249 \mathrm{~m}^{3}(4.9 \%)$. The remaining 831 dumping sites are located in the narrow areas with less strict regime (water protection area IIB).

Most of the illegal dumping sites are located in overgrown areas and hidden from view. More than half of the dumping sites (covering $46.0 \%$ of the surface area and containing $39.6 \%$ of the volume) are located in bushes and thin or dense forests. Barren areas »only« host 216 illegal dumping sites, and some

Figure 7: Depth of groundwater under illegal dumping sites.

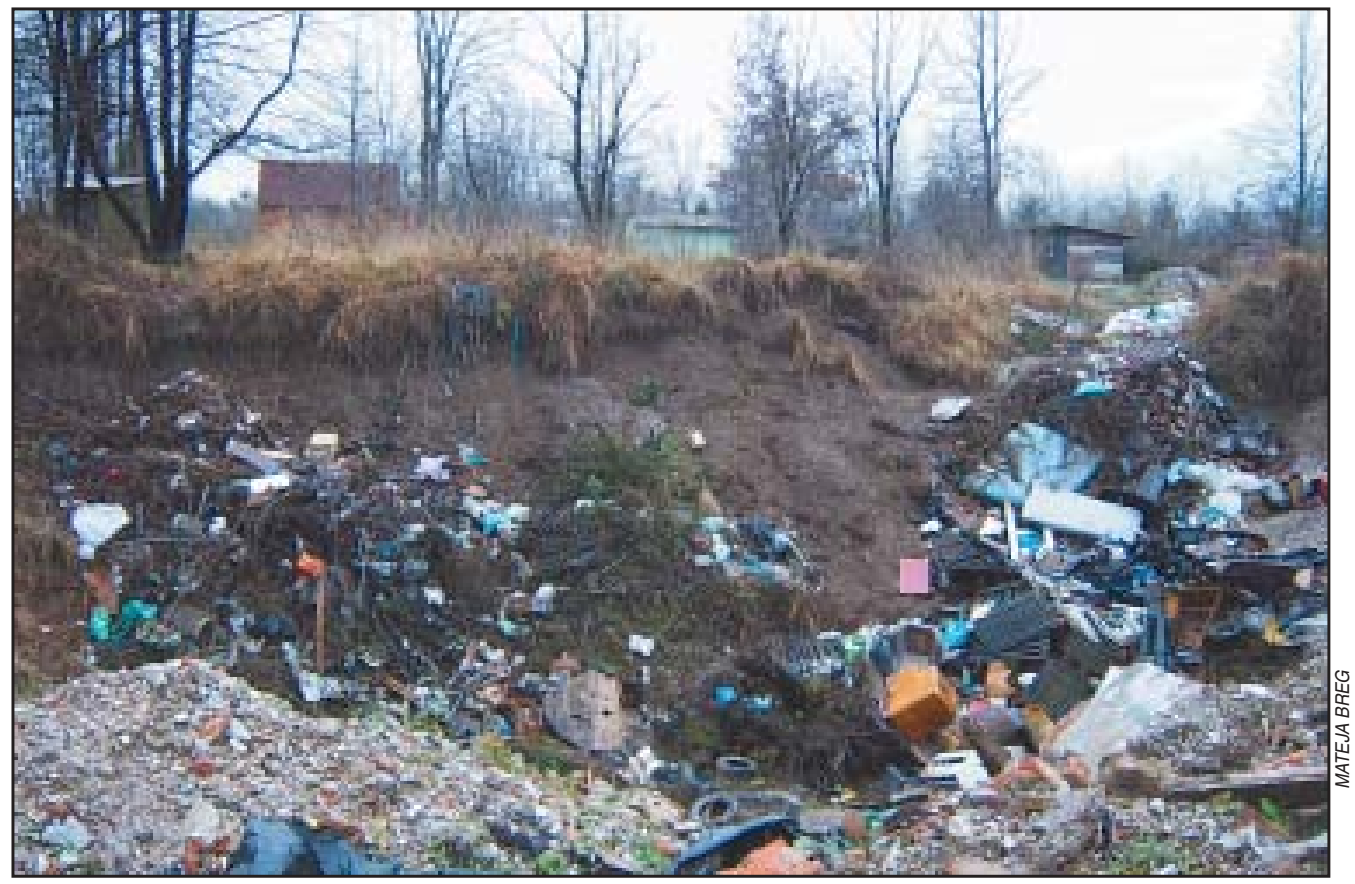

Figure 8: Illegal dumping site in a gravel pit near a garden allotment area. 


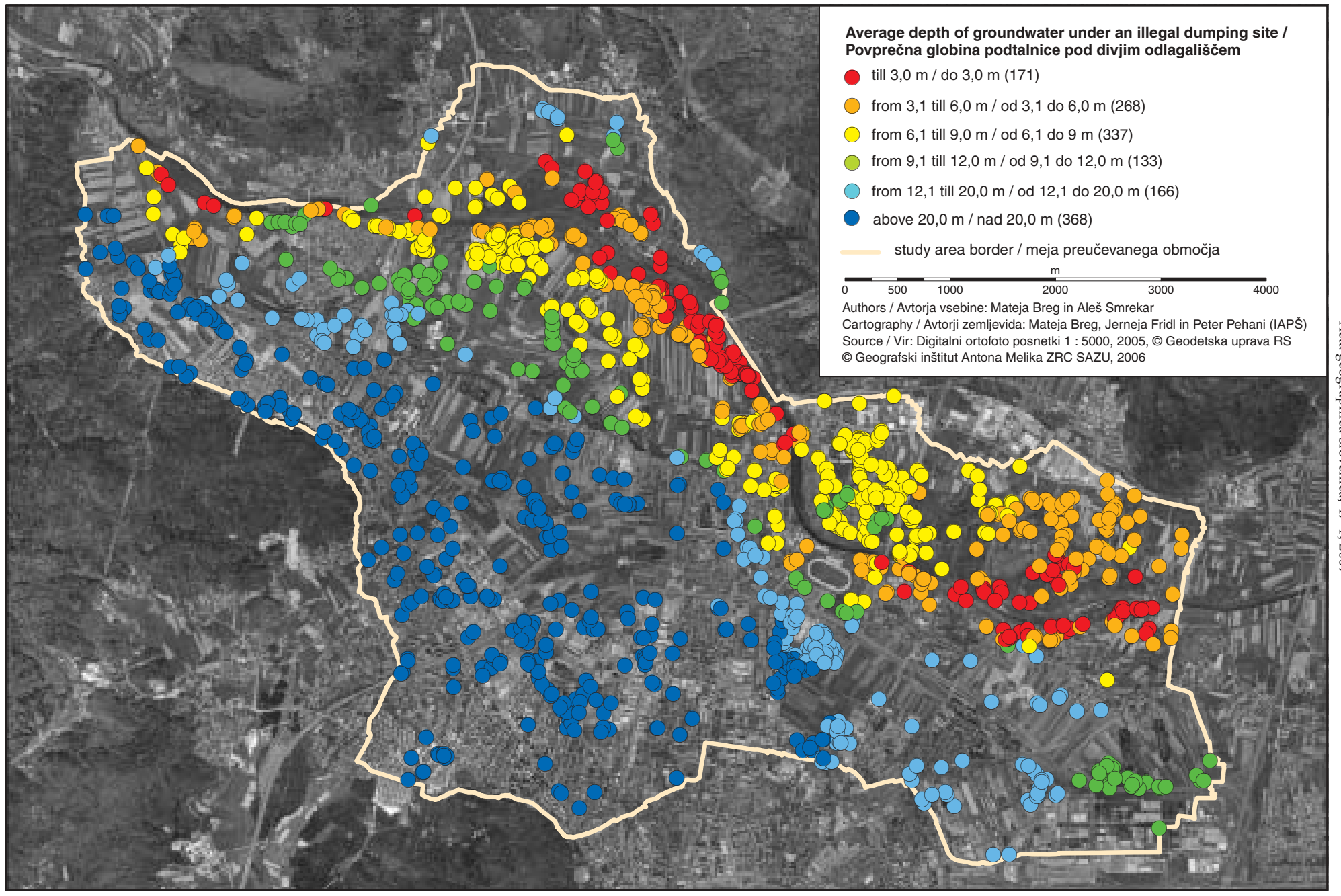


Figure 9: Activity of illegal dumping sites.

waste is also found on recent unovergrown gravel pits. We even registered 79 illegal dumping sites with a total volume of $1,092 \mathrm{~m}^{3}$ or $0.5 \%$ of all waste on built-up land.

There are 126 illegal dumping sites in gravel pits, where some $61.2 \%$ of the registered waste with a volume of $128,150 \mathrm{~m}^{3}$ is found, covering $55,873 \mathrm{~m}^{2}$ or $46.2 \%$ of total surface area of the dumping sites. On Ljubljansko polje, we registered 87 gravel pits, and only 15 of them were free of waste. Gravel pits began to appear to a greater extent after 1958 (Smrekar et al. 2005).

Relative to the quantity of waste, inactive dumping sites lead with more than half (51.4\%), while fully active dumping sites contribute just under a third (30.9\%). There is a reasonable suspicion that additional quantities of past waste are hidden below 359 dumping sites (24.8\%). Unfortunately, this suspicion applies in particular at the larger dumping sites where we registered $87,009 \mathrm{~m}^{3}$ or $41.5 \%$ of the total quantity of waste.

Illegal dumping sites are mostly found at locations remote from settlements and major roads. One of the most important factors for their existence is the accessibility of the location where waste can be dumped. Access is usually easy on a gravel plain, so it is not surprising that more than two thirds (67.5\%) of illegal dumping sites are located less than five meters from access roads.

Various routes lead to illegal dumping sites and the various types of barriers set up on asphalt and dirt roads as well as on wagon tracks and footpaths should be the greatest hindrance to the unobstructed delivery of waste material. Unfortunately, it is possible to get around them in many cases. An interesting fact is that 222 dumping sites with $42.9 \%$ of the total surface area and $55.0 \%$ of the total volume are only accessible by passing road barriers, which indicates that the competent authorities are trying to limit illegal dumping. Unfortunately, however, new piles of waste have started to accumulate before the barriers.

The majority of the 57 recorded barriers are concentrated along the banks of the Sava River, especially downstream from Brod on the right bank and from Črnuče on the left bank of the river. The most frequently employed barriers are gates and embankments. In many places, a smaller or larger pile of waste

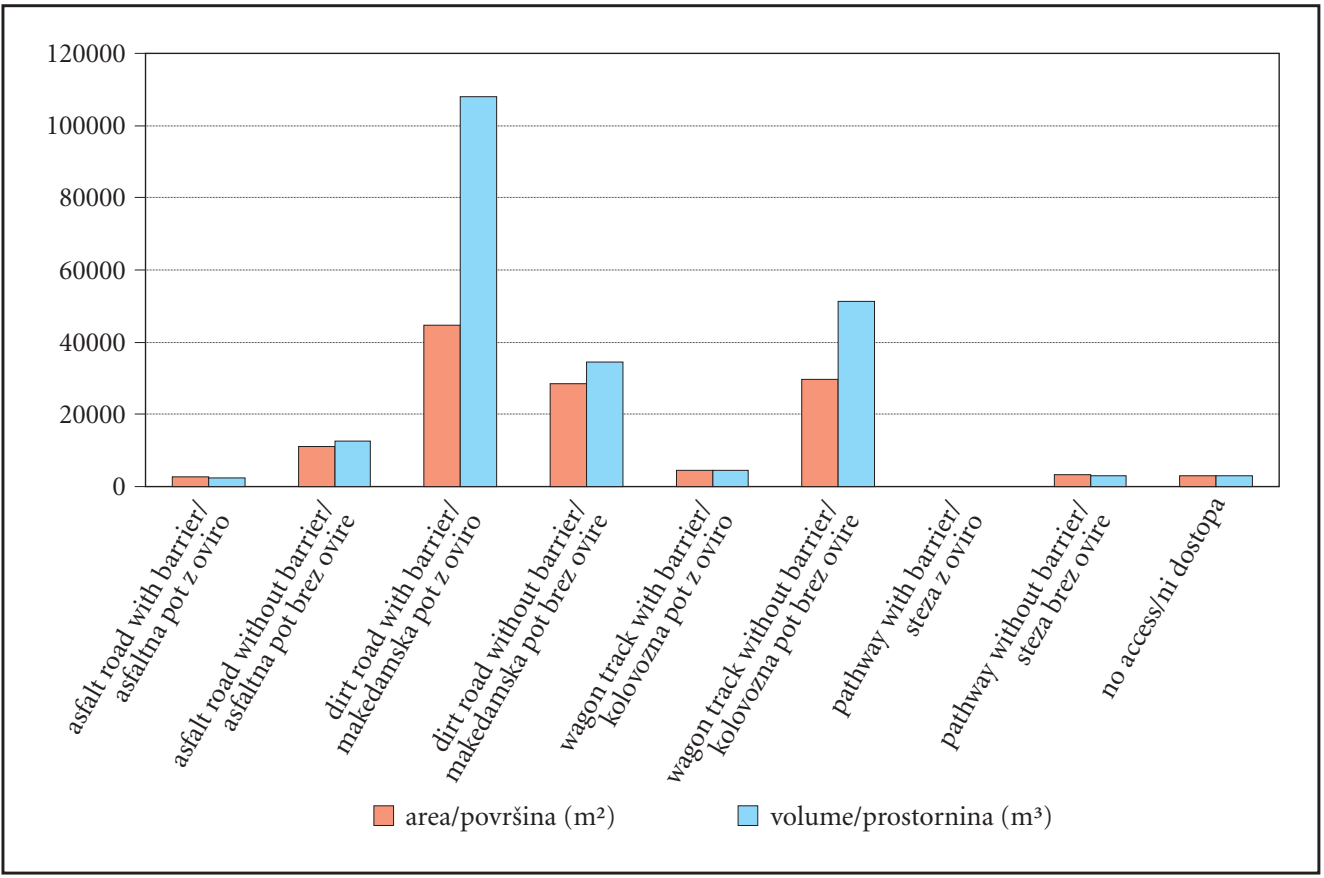

Figure 10: Accessibility of illegal dumping sites relative to their surface area $\left(\mathrm{m}^{2}\right)$ and volume $\left(\mathrm{m}^{3}\right)$. 


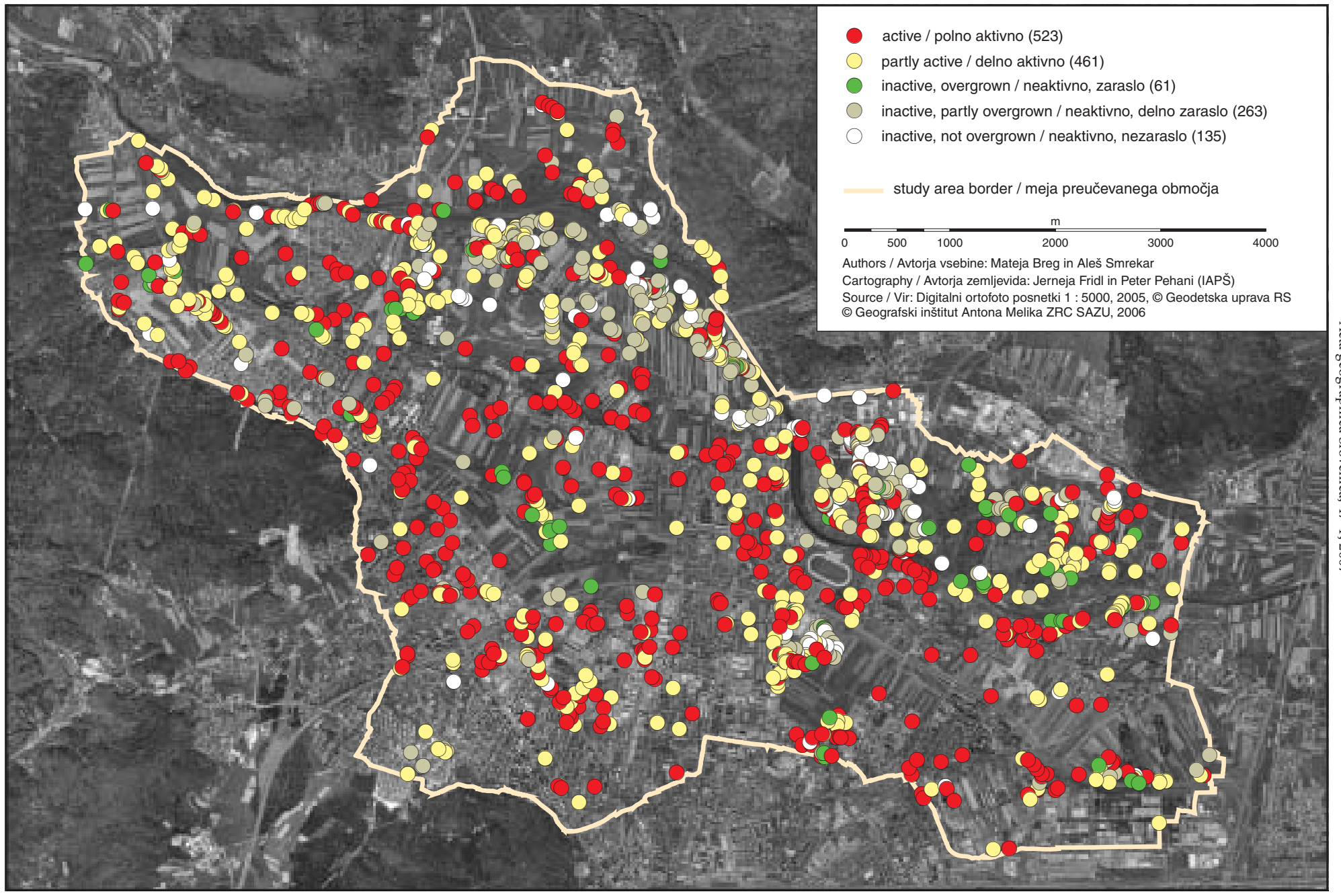


on a dirt road serves as a road block (construction material, car tires, piles of rock, etc.), and in the forest in Jarški prod trees have been felled especially for this purpose. Ditches have been dug in places, although such barriers can be filled in with waste material, and we also encountered concrete pyramids. Some 159 dumping sites $(11.0 \%)$ are fenced. There are also several dozen (somewhat ineffective) information and warning signs prohibiting dumping or some similar warning.

The problem of undesirable pollution of the natural environment can only be solved by the permanent management of the affected areas with regular monitoring, a system of penalties, and their cleanup. It is also necessary to raise the awareness of potential polluters through education by providing information and in particular informing people of the dumping ban. Monitoring by the inspection service and the police should be stricter, and those who do not respect the notices and circumvent the barriers should be penalized. Setting up gates on access roads should be the last act in the series of warnings that dumping waste is no longer allowed in a certain area.

\section{Priority rehabilitation of dumping sites}

In the long run, the cost for the periodic rehabilitation of larger dumping sites is higher than for regular collection of material from smaller dumping sites, although this only applies when such a system is already established (Berden Zrimec et al. 2004). It is therefore unacceptable that dumping reoccurs once rehabilitation has taken place.

In time, it will be necessary to rehabilitate all illegal dumping sites; however, due to the large quantity of waste it is unrealistic to expect this to happen in one go. We have therefore established a priority schedule for the rehabilitation of the entire Ljubljansko polje area and of Jarški prod in particular on the basis of assessments in four categories.

Due to the substantial weight given to the vulnerability of the dumping site area, which contributes half of all possible points, it is not surprising that the 58 illegal dumping sites ranked in the first priority class with 71 to 93 points (of the theoretically possible 100) are on the majority of the surveyed areas located in the vicinity of pumping stations. This is particularly characteristic for the area of the Jarški prod pumping station. Some of the dumping sites are located downstream from the pumping stations, but substantial pumping creates depression funnels, which means they are still within the water catchment areas. Some of the most contaminated illegal dumping sites are located in former gravel pits where there is only a small distance to the groundwater.

Some 218 illegal dumping sites (15.1\% of all) acquired between 61 and 70 points and were ranked in the second priority class. On Ljubljansko polje, they are concentrated particularly in four areas, with most located in Jarški prod. There are also major concentrations on the right bank of the Sava River between Jarše and Sneberje, north of Kleče, and southwest of Hrastje. A considerable number are located in former gravel pits.

Dumping sites in the third priority class with 51 to 60 points, where 491 (34.0\%) of the illegal dumping sites are ranked, are scattered across all the surveyed areas in no particular pattern.

In the fourth priority class with 41 to 50 points there are 493 (34.1\%) illegal dumping sites. These too are quite evenly distributed, although it is clear that there are fewer in the vicinity of pumping stations, particularly in the areas around Jarški prod and Hrastje.

The fifth priority class contains 183 illegal dumping sites with less than 40 points (the lowest number is 26). They are not usually found in the vicinity of the pumping stations, and since their waste is not very hazardous, the need for their rehabilitation is the smallest.

\section{Conclusion}

Despite the uniform criteria for registering dumping sites with at least one cubic meter of waste, a comparison of various surveys of the area of the entire City Municipality of Ljubljana or its individual parts shows considerable discrepancies. The table below presents a comparison of the results of surveys made 


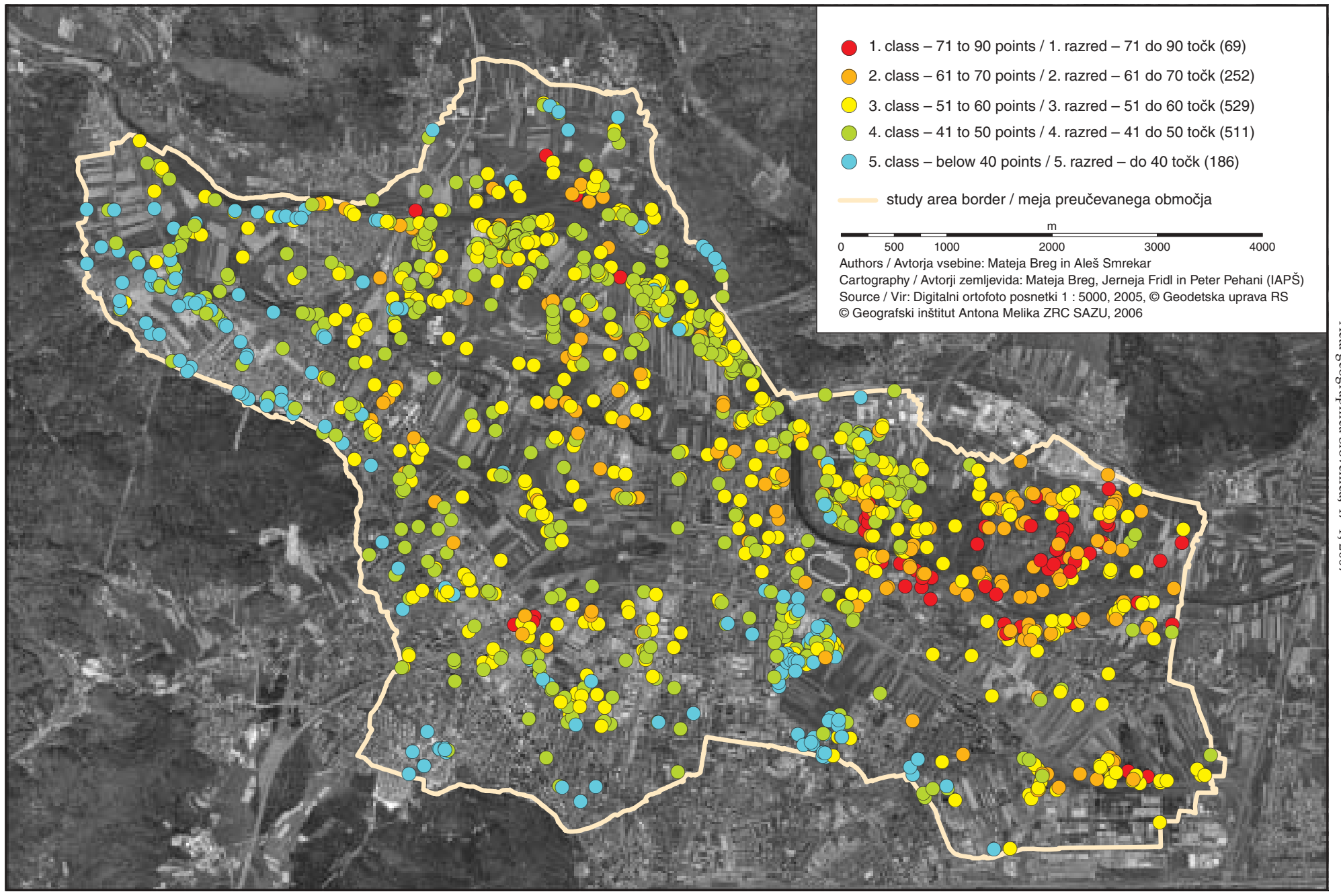


in 1996 (Oikos d. o. o.), 2000 (diploma thesis by Simon Kušar that only treated the open area of Ljubljansko polje), 2004 (Institute for Bioelectromagnetics and New Biology), and 2006 (Anton Melik Geographical Institute of the Scientific Research Centre of the Slovenian Academy of Sciences and Arts).

Table 1: Comparison of results of various surveys of illegal dumping sites in the City Municipality of Ljubljana.

\begin{tabular}{llcccr}
\hline Year & Area included & $\begin{array}{c}\text { Surface } \\
\text { area }\left(\mathrm{km}^{2}\right)\end{array}$ & $\begin{array}{c}\text { Number of surveyed } \\
\text { illegal dumping sites }\end{array}$ & $\begin{array}{c}\text { Estimated surface } \\
\text { area }\left(\mathrm{m}^{2}\right)\end{array}$ & $\begin{array}{r}\text { Estimated } \\
\text { volume }\left(\mathrm{m}^{3}\right)\end{array}$ \\
\hline 1996 & City Municipality of Ljubljana & 275.0 & 457 & 70,448 & 32,761 \\
2000 & Open area of Ljubljansko polje & unknown & 359 & 163,400 & 84,000 \\
2004 & City Municipality of Ljubljana & 275.0 & 278 & unknown & 100,000 \\
2006 & Part of water protection area in the City & 45.8 & 1482 & 122,573 & 211,279 \\
& Municipality of Ljubljana & & & \\
\hline
\end{tabular}

The substantial differences obtained are probably the result of a number of factors: differences in the exactness of data collected, the subjectivity of surveyors, and the season the data was collected (visibility is substantially better in winter without a snow blanket).

Solving the problem of illegal dumping sites requires two simultaneous approaches. The first is to rehabilitate existing dumping sites and thus remove point sources and larger plane sources of contamination of the underground water, and the concurrent second approach is to effectively prevent the occurrence of new dumping sites, strictly penalize violators, and organize campaigns to raise environmental awareness.

So far, there has not been enough will - and consequently funds - to resolve this unfavourable situation. Recently, however, the city authorities have apparently realized the need to take action, shown by the fact that in addition to the waste collection carried out by Snaga the first more comprehensive steps

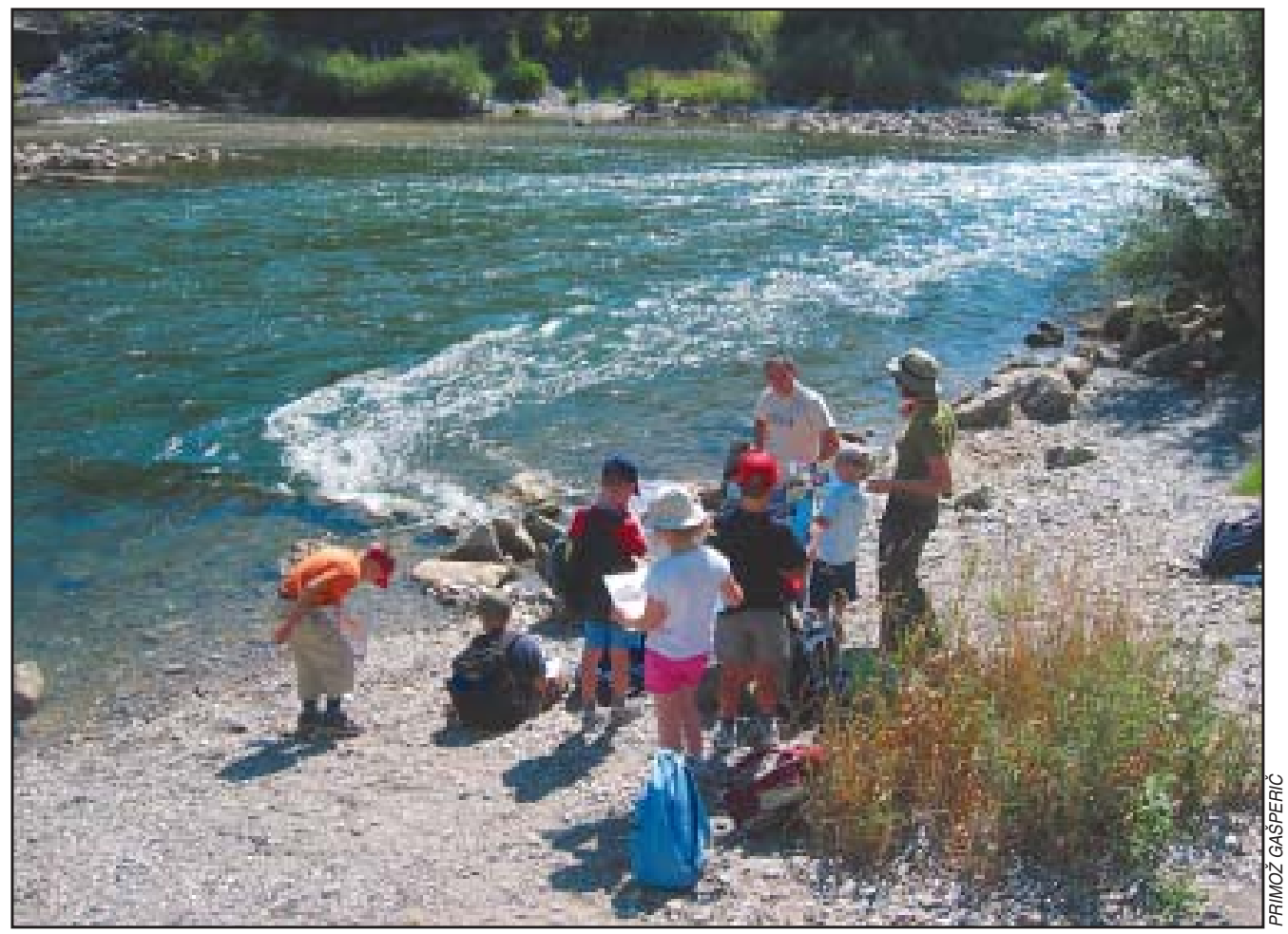

Figure 12: Raising awareness in the youngest is a step toward the conservation of the environment and a thoughtful attitude toward space. 
have been taken. A rehabilitation project for the most polluted area of Jarški prod is in the preparation phase, which will be followed by a pilot rehabilitation project.

The Spatial Plan of the City Municipality of Ljubljana (2002) envisages this area as a forest area with emphasized ecological and recreational significance. A system of walking and cycling paths could be arranged along the Sava River that with the appropriate rehabilitation would give the area new quality dimensions. There are ideal possibilities here for a water education trail where various items and topics could be presented such as the operation of pumping stations, the dry riverbed of a former watercourse, the regulation of a riverbed, a gravel pit with a profile of the cover layer and gravel on an alluvial plain as an inappropriate source of construction material, and an illegal dumping site as an inappropriate use of a gravel pit just above the groundwater table, etc.

To successfully implement the established goals of waste management, it is necessary to inform, educate, and raise awareness. Endeavours without the support and appropriate level of environmental awareness of the local population will not achieve the goal, a clean and healthy local landscape. People must change their lifestyles in order to enable the spatial values to become a part of their lifestyles. It is obvious that a non-problematic environment does not represent a value for many people. Currently, less than a quarter of the population in the surveyed area of Ljubljansko polje hold this particular value (Smrekar 2006). Informing, educating, and raising awareness of individuals and social groups guarantees the formation of a mature and responsible attitude toward the world in which we live (Urbanc, Fridl 2007). This attitude must become a value that ranks highly in the value scale of the people. For ordinary people, a value is a concept of the basic categories of something that is desirable, good, and positive (Urbanc 2006), or as defined by the Slovar slovenskega knjižnega jezika (Dictionary of the Slovene Written Language, 1995), a value is something people recognize as a major asset and therefore give it priority.

These and other endeavours on the level of the City Municipality of Ljubljana have been undertaken particularly by the Institute for Environmental Protection of the Republic of Slovenia. One of its missions is to publish information and motivation publications such as Environment in the City Municipality of Ljubljana (2004) and A Guide to the Protection of Underground Water in the City Municipality of Ljubljana (2005).

This article is the result of Dumping Sites in the Water Protection Area Important for the Supply of the City Municipality of Ljubljana with Drinking Water research projects undertaken by the Anton Melik Geographical Institute of the Scientific Research Centre of the Slovenian Academy of Sciences and Arts in cooperation with Javno podjetje Vodovod-Kanalizacija d. o. o. (Ljubljana's public water utility) and the Chemical Institute. For the financing, we would like to thank the Department for Culture and Research Activities of the City Municipality of Ljubljana and Javno podjetje Vodovod-Kanalizacija d. o. o.

\section{References}

Auersperger, P., Čenčur Curk, B., Jamnik, B., Janža, M., Kus, J., Prestor, J., Urbanc, J. 2005: Dinamika podzemne vode. V: Podtalnica Ljubljanskega polja. Geografija Slovenije 10. Ljubljana.

Berden Zrimec, M., Ružič, R., Leskovar, R. 2004: Popis divjih odlagališč odpadkov (črne deponije) na območju Mestne občine Ljubljana. BION, Inštitut za bioelektromagnetiko in novo biologijo. Ljubljana.

Bračič Železnik, B., Kladnik, D., Rejec Brancelj, I., Smrekar, A., 2005. Mestna raba tal. V: Podtalnica Ljubljanskega polja. Geografija Slovenije 10. Ljubljana.

Bračič Železnik, B, Pintar, M., Urbanc, J. 2005a: Naravne razmere vodonosnika. V: Podtalnica Ljubljanskega polja. Geografija Slovenije 10. Ljubljana.

Bračič Železnik, B., Jamnik B. 2005: Javna oskrba s pitno vodo. V: Podtalnica Ljubljanskega polja. Geografija Slovenije 10. Ljubljana.

Breg, M., Urbanc, M. 2005. Gramoznice in dileme (ne)trajnostnega razvoja degradirane obrečne pokrajine. IB 34-4. Ljubljana.

Breg, M., Fridl, M, Kladnik, D., Smrekar, A. 2005: Vrednotenje nedovoljenih odlagališč odpadkov glede na nujnost njihove sanacije. Geografski vestnik 77-1. Ljubljana.

Breznik, M. 1988: Analiza odlokov o zaščiti ljubljanskih virov pitne vode. Ljubljana.

Frantar, P., Kladnik, D., Petek, F., Rejec Brancelj, I. 2005: Raba tal. V: Podtalnica Ljubljanskega polja. Geografija Slovenije 10. Ljubljana.

Kladnik, D. (ur.), Lovrenčak, F. (ur.), Orožen Adamič M. (ur.) 2005: Geografski terminološki slovar. Ljubljana. 
Kladnik, D., Rejec Brancelj, I., Smrekar, A., 2002. Integralna obremenjenost prodnih ravnin Slovenije. Dela 18. Ljubljana.

Kladnik, D., Rejec Brancelj, I., Smrekar, A. 2004: Kmetijsko obremenjevanje. V: Podtalnica Ljubljanskega polja, Geografija Slovenije 10. Ljubljana.

Kobal, J., Spruk, B., Špendl, R. 1999: Popis odlagališč odpadkov v Mestni občini Ljubljana. Oikos. d. o. o. Ljubljana.

Kušar, S. 2000: Geografske značilnosti odlagališč odpadkov na Ljubljanskem polju. Diplomska naloga. Ljubljana.

Lanz, K., Scheuer, S. 2001: Priročnik za razlago politike EU o vodah na podlagi okvirne direktive o vodah. Umanotera. Ljubljana.

Notar, M., Loose, A., Jankovič, M., Jazbinšek Sršen, N., Logar, M., Strojin Božič, Z., Piltaver, A. 2004: Okolje v Mestni občini Ljubljana. Ljubljana.

Odlok o oskrbi s pitno vodo. Uradni list Republike Slovenije 17/2006. Ljubljana.

Orožen Adamič, M., Pleskovič, B. 1975: Problemi okolja in odlaganja trdih odpadkov v Ljubljani. Geografski vestnik 47. Ljubljana.

Plut, D., 2003. Geografske teoretične in metodološke zasnove proučevanja degradacije okolja. Študijsko gradivo za Varstvo geografskega okolja. Filozofska fakulteta, Ljubljana.

Popis prebivalstva, gospodinjstev in stanovanj v Republiki Sloveniji leta 2002. Statistični urad Republike Slovenije. Ljubljana, 2003.

Pravilnik o kriterijih za določitev vodovarstvenega območja. Uradni list Republike Slovenije 64/2004. Ljubljana.

Pravilnik o obremenjevanju tal z vnašanjem odpadkov. Uradni list Republike Slovenije 3/2003 (z dopolnitvami). Ljubljana.

Pravilnik o odlaganju odpadkov. Uradni list Republike Slovenije 5/2000 (z dopolnitvami). Ljubljana.

Pravilnik o pitni vodi. Uradni list Republike Slovenije Republike Slovenije 19/2004 (z dopolnitvami). Ljubljana.

Pravilnik o ravnanju z odpadki. Uradni list Republike Slovenije 84/1998 (z dopolnitvami). Ljubljana.

Prostorski plan Mestne občine Ljubljana, Prostorska zasnova. Ljubljana, 2002.

Rejec Brancelj, I. 2001: Kmetijsko obremenjevanje okolja v Sloveniji. Ljubljana.

Smrekar, A., 2004. Reduced Permeation of Precipitation Water into Groundwater on Ljubljansko polje. Acta Geographica Slovenica 44-2. Ljubljana.

Smrekar, A., 2006. Zavest ljudi o pitni vodi. Geografija Slovenije 12. Ljubljana.

Smrekar, A. Rejec Brancelj, I. Breg, M. 2006: Zdrava $\mathrm{H}_{2} \mathrm{O}$ zame!. Ljubljana.

Smrekar, A., Breg, M., Fridl, J., Kladnik, D., Urbanc, M., Bračič-Železnik, B., Jamnik, B., Grilc, V., Husić, M., Kušar, S. 2005: Izdelava katastra in predloga prednostne sanacije odlagališč odpadkov vodozbirnega območja črpališča Jarški prod. Znanstvenoraziskovalni center Slovenske akademije znanosti in umetnosti. Ljubljana.

Smrekar, A., Breg, M., Slavec, P., Bračič-Železnik, B., Jamnik, B., Grilc, V., Husić, M. 2006: Odlagališča odpadkov na vodovarstvenem območju, pomembnem za oskrbo Mestne občine Ljubljana s pitno vodo. Znanstvenoraziskovalni center Slovenske akademije znanosti in umetnosti. Ljubljana.

Slovar slovenskega knjižnega jezika. 1995. Ljubljana.

Snaga - javno podjetje. Arhivsko gradivo. 2006. Ljubljana.

Šebenik, I. 1994: Pokrajinske značilnosti manjših neurejenih odlagališč odpadkov v Sloveniji. Geographica Slovenica 26-1. Ljubljana.

Urbanc, M., 2006: Report of the R. A. V. E. Space educational seminar for teachers in Portorož. Tipkopis.

Urbanc, M., Breg, M., 2005. Gravel plains in urban areas: gravel pits as an element of degraded landscapes. Acta Geographica Slovenica 45-2. Ljubljana.

Urbanc, M., Fridl, J. 2007: Izobraževanje mladih kot pomemben dejavnik trajnostnega razvoja: na primeru projekta R. A. V.E. Space. Rokopis za simpozij slovenski regionalni dnevi.

Uredba o odlaganju odpadkov na odlagališčih. Uradni list Republike Slovenije 32/2006. Ljubljana.

Uredba o standardih kakovosti podzemne vode. Uradni list Republike Slovenije 100/2005. Ljubljana.

Uredba o vodovarstvenem območju za vodno telo vodonosnika Ljubljanskega polja. Uradni list Republike Slovenije 120/2004. Ljubljana.

Viler Kovačič, A. 2001: Ravnanje z odpadki. Ljubljana. 
Vodnik o varovanju podzemne vode v Mestni občini Ljubljana. Ljubljana, 2005.

Zakon o ravnanju z odpadki. Uradni list Socialistične Republike Slovenije 8/1978. Ljubljana. Zakona o varstvu okolja. Uradni list Republike Slovenije 32/1993. Ljubljana.

Zakon o varstvu okolja. Uradni list Republike Slovenije 41/2004. Ljubljana.

Zakon o vodah. Uradni list Republike Slovenije 67/2002. Ljubljana. 


\section{Odlagališča odpadkov na vodovarstvenem območju Ljubljanskega polja, glavnem viru oskrbe Ljubljane s pitno vodo}

UDK: 911.3:628.472.2(497.4Ljubljansko polje)

628.472.2:504.5(497.4Ljubljansko polje)

COBISS: 1.01

IZVLEČEK: Ljubljansko polje je prodna ravnina vzdolž reke Save, severno od Ljubljane. Kljub temu, da se nanj nezadržno širi pozidava, je vsaj v osrednjem delu ravno zaradi vodovarstvenega območja ohranilo značaj sorazmerno intenzivno obdelane kmetijske pokrajine. Podtalnico v prodnem vodonosniku ogrožajo divja odlagališča odpadkov. Na najožjem in ožjem vodovarstvenem območju Ljubljanskega polja smo našli, popisali in preučili 1445 divjih odlagališč odpadkov. Njihova skupna površina je $120.816 \mathrm{~m}^{2}$, skupna prostornina odpadkov pa $209.422 \mathrm{~m}^{3}$. Med vsemi odpadki jih je dobra sedmina $(13,5 \%)$ nevarnih. Evidentirali smo še 86 gramoznic, 47 obvestilno-opozorilnih tabel in 57 ovir na dovoznih poteh. Sčasoma bo vsa divja odlagališča odpadkov treba sanirati, vendar je zaradi velike količine odpadkov nerealno pričakovati, da bi to naredili naenkrat, zato smo določili prednostni vrstni red sanacije.

KLJUČNE BESEDE: geografija, varstvo okolja, divje odlagališče odpadkov, vodovarstveno območje, Ljubljana, podtalnica, sanacija

Uredništvo je prejelo prispevek 28. februarja 2007.

NASLOVI:

Mateja Breg, univ. dipl. geografinja

Geografski inštitut Antona Melika

Znanstvenoraziskovalni center Slovenske akademije znanosti in umetnosti

Gosposka ulica 13, SI - 1000 Ljubljana, Slovenija

E-pošta: mateja.breg@zrc-sazu.si

Drago Kladnik, dr.

Geografski inštitut Antona Melika

Znanstvenoraziskovalni center Slovenske akademije znanosti in umetnosti

Gosposka ulica 13, SI - 1000 Ljubljana, Slovenija

E-pošta: drago.kladnik@zrc-sazu.si

Aleš Smrekar, dr.

Geografski inštitut Antona Melika

Znanstvenoraziskovalni center Slovenske akademije znanosti in umetnosti

Gosposka ulica 13, SI - 1000 Ljubljana, Slovenija

E-pošta: ales.smrekar@zrc-sazu.si

\section{Vsebina}

1 Uvod 95

2 Oris obravnavanega območja 95

3 Metode 96

4 Zakonske določbe 97

$5 \quad$ Temeljne značilnosti preučenih objektov 98

5.1 Velikostni parametri odlagališč odpadkov 99

5.2 Sestava odpadkov 99

5.3 Okoljski parametri odlagališč odpadkov $\quad 100$

6 Prednostna sanacija odlagališč odpadkov 101

7 Sklep 102

8 Literatura 103 


\section{Uvod}

V reliefno razgibani Sloveniji so prodne ravnice z vodonosniki na eni strani najpomembnejši vir pitne vode, saj se iz njih oskrbuje več kot $90 \%$ prebivalstva, na drugi pa gospodarsko, prometno in poselitveno težišče države (Kladnik in ostali 2002). V zadnjih desetletjih so si ta prostor izrazito podredile urbane dejavnosti in dodobra izpodrinile kmetijstvo, ki pa je glede na površino še vedno njegov največji uporabnik. Kljub številnim omejitvam na vodovarstvenih območjih, so se mesta razširila tudi tja, še zlasti na območja pasov z manj strogimi režimi varovanja (Bračič Železnik et al. 2005; Rejec Brancelj 2001), tako da lahko govorimo o rurbanih območjih.

Sodobna mesta $\mathrm{v}$ gospodarsko razvitih državah bistveno odstopajo od konceptov trajnostnega razvoja, saj za zadovoljevanje snovnih in energijskih potreb ter za odlaganje različnih emisij in odpadkov potrebujejo zelo obsežna produktivna zemljišča (Hille 1994, Hille 1997; v Plut 2003). Degradacija urbane pokrajine izvira iz nesklenjenosti snovnih krogov (na primer odpadki) in rabe neobnovljivih energetskih virov (na primer gramoz), kar povzroča pokrajinske obremenitve ter spremembe v pokrajinski sestavi in dinamiki mest ter njihove okolice (Breg, Urbanc 2005; Urbanc, Breg 2005).

Obrečni prostor na prodnih ravninah je marsikje odmaknjen pogledu, zato je že od nekdaj izpostavljen nedovoljenim posegom urbanega prebivalstva, s čimer postaja čedalje bolj degradiran. Obrečna pokrajina pogosto ni našla pravega mesta $\mathrm{v}$ vrednostnem sistemu prebivalstva, ki je v njej videlo zlasti naravni vir in razpoložljiv prostor za nedovoljene posege. Za to so dober dokaz gramoznice in divja odlagališča. Število slednjih in njihov negativen vpliv sta večja, kot smo si pripravljeni priznati, s tem pa so zmanjšane tudi možnosti za hitro in celovito ureditev te problematike. V Sloveniji so tovrstna odlagališča razmeroma nov, nezaželen in moteč del pokrajine.

Zaradi raznovrstnih negativnih vplivov divjih odlagališč odpadkov si družbena skupnost prizadeva organizirano preprečevati nastajanje novih divjih odlagališč in kopičenje dodatnih odpadkov na že obstoječih. Temeljna načela ravnanja $z$ odpadki so:

- reševanje problematike odpadkov na izvoru (zmanjševanje količine),

- preventiva,

- ločeno zajemanje snovnih tokov odpadkov,

- vračanje naravi,

- racionalnost in postopnost vzpostavitve mreže objektov in naprav, namenjenih ravnanju z odpadki,

- racionalnost ravnanja s prostorom,

- varovanje naravnih in kulturnih vrednot ter

- saniranje divjih odlagališč.

Eden izmed glavnih ukrepov uveljavljanja dolgoročnih načel ravnanja z odpadki je izobraževanje, usposabljanje in informiranje. Odpori prebivalstva do ustreznega ravnanja z odpadki se pojavljajo zlasti na lokalni, denimo ji izvedbeni ravni, medtem ko so posamezniki kot del širše skupnosti bolj pozitivno nastrojeni. Kakorkoli že, odpadki so naša stvarnost in z njihovimi negativnimi učinki se moramo soočiti ter jih kar najbolj učinkovito reševati.

\section{Oris obravnavanega območja}

V vodonosnih prodno-peščenih in konglomeratnih plasteh, ki zapolnjujejo udorino Ljubljanskega polja, je količina podtalnice ocenjena na do 100 milijonov $\mathrm{m}^{3}$. Gre za enega največjih rezervoarjev podzemne vode v Sloveniji, ki predstavlja naravni vir regionalnega pomena (Bračič Železnik in ostali 2005a). Globina do podtalnice je odvisna od njene gladine in višine terena. Podtalnica na visoki terasi pri Vižmarjih je v globini več kot $30 \mathrm{~m}$, med Ježico in Zadobrovo pa le med 5 in $10 \mathrm{~m}$. Letni režim spreminjanja gladine podtalnice v obdobju 1987-2005 kaže na precejšnje letno kolebanje. To na območju Broda doseže od 4 do $6 \mathrm{~m}$, v Klečah od 5 do $6 \mathrm{~m}$ in v Hrastju od 1,5 do $2 \mathrm{~m}$.

$\mathrm{V}$ splošnem se podtalnica pretaka $\mathrm{v}$ smeri od severozahoda proti jugovzhodu oziroma vzhodu. Hitrost njenega premikanja znaša $\mathrm{v}$ zahodnem delu vodonosnika med 5 in 10 metrov na dan, v vzhodnem delu pa večinoma med 10 in $20 \mathrm{~m} /$ dan (Auersperger in ostali 2005).

Glavni vir napajanja vodonosnika Ljubljanskega polja je reka Sava, drugotni pa infiltracija padavinske vode, ki pa je zaradi urbane rabe ponekod zelo zmanjšana (Smrekar 2004). Sava v zgornjem delu napaja 
vodonosnik, v spodnjem delu pa podtalnica odteka nazaj v njeno strugo (Auersperger in ostali 2005). Drugi največji površinski tok na Ljubljanskem polju je reka Ljubljanica. Njen tok je počasen, zablatena struga pa močno omejuje izmenjavo vode med reko in vodonosnikom.

Mestna občina Ljubljana oskrbuje prebivalstvo in podjetja iz več vodnih virov. Najizdatnejša črpališča pitne vode so na Ljubljanskem polju; tamkajšnje vodarne so vključene v centralni vodovodni sistem. $42,98 \mathrm{~km}^{2}$ veliko obravnavano območje je po Uredbi o vodovarstvenem območju za vodno telo vodonosnika Ljubljanskega polja (Uradni list Republike Slovenije (v nadaljevanju UL RS) 120/2004) na najožjih $(0, \mathrm{I})$ in ožjih (IIA, IIB) vodovarstvenih območjih.

Slika 1: Najožja in ožja vodovarstvena območja na Ljubljanskem polju.

Glej angleški del prispevka.

V prvih 606 ljubljanskih hiš je voda pritekla že 17. maja 1890. Vodarna v Klečah je ostala srce vodovodnega sistema Ljubljane. Leta 1953 se ji je pridružila vodarna Hrastje, leta 1955 vodarna Šentvid in leta 1982 še vodarna Jarški prod (Bračič Železnik, Jamnik 2005).

Podzemna voda je tesno povezana tako z naravnimi razmerami kot s človekovimi dejavnostmi. Njena ranljivost je odvisna od hidrogeoloških, hidroloških in pedoloških razmer. Nanjo lahko vplivajo tudi različna gradbena dela in izkopi, na primer odvzem gramoza. Nelegalne gramoznice so zunaj strnjenega urbanega območja, zlasti na nižjih terasah ob Savi.

Štiri legalne gramoznice večjega obsega so v Stanežičah, na območju Dovježa jugozahodno od krožišča $v$ Tomačevem in v Obrijah. Vse so $v$ fazi sanacije. Opuščene gramoznice $k$ sreči niso v večji meri zasipavali z odpadki, saj so jih po letu 1924, ko se je začel njihov organiziran odvoz, odvažali zlasti v južne dele Ljubljane (Orožen Adamič, Pleskovič 1975).

Čistilna sposobnost prodnih in peščenih krovnih plasti je učinkovita pri biološkem onesnaženju, ne pa tudi pri kemičnem. Koncentracija onensaževal se na splošno zmanjšuje z razdaljo, ki jo prepotujejo skozi tla. Topljivih odpadkov, med katere spadajo gnojila in nekateri industrijski odpadki, se s filtracijo ne da odstraniti. Kovinske raztopine na biološke procese niso občutljive.

Iz analize sprememb rabe tal (Frantar in ostali 2005) lahko sklepamo, da je za obremenjevanje podtalnice najpomembnejši razlog urbanizacija. Zaradi nje se je obseg kmetijskih zemljišč skrčil, čeprav se je kmetijska raba še bolj približala reki Savi (Kladnik in ostali 2004). Kot posebna, zelo številna skupina uporabnikov kmetijskega prostora so se s svojevrstnimi obdelovalnimi in drugimi navadami uveljavili vrtičkarji.

\section{Zakonske določbe}

Normativna ureditev ravnanja z odpadki je bila dolga leta eno najbolj problematičnih področij varstva okolja v Sloveniji. Poglavitni razlogi so dosedanji družbeni odnos do odpadkov in ravnanje z njimi, pomanjkanje navpične in vodoravne upravne in strokovne usklajenosti ter organiziranosti, ekonomski ukrepi ter naravne značilnosti slovenskega prostora (Viler Kovačič 2001).

Do uveljavitve Zakona o varstvu okolja v letu 1993 je celovit sistem ravnanja z odpadki urejal Zakon o ravnanju z odpadki (UL SRS 8/1978). V njem je bila vpeljana obveznost, da je treba preprečevati in omejevati nastajanje odpadkov, skrbeti za njihovo ponovno uporabo in da je treba z njimi ravnati smotrno, neškodljivo in okolju primerno.

Z uveljavitvijo Zakona o varstvu okolja (UL RS 32/1993 z dopolnitvami) se je na novo pristopilo k reševanju problematike varstva okolja nasploh in s tem tudi k reševanju problematike ravnanja z odpadki, ki je postajala vse bolj pereča. Tem smernicam sledi tudi prenovljen Zakon o varstvu okolja (UL RS 41/2004 $\mathrm{z}$ dopolnitvijo).

Razcvet normativne ureditve ravnanja z odpadki se je dejansko začel šele leta 1998 s sprejetjem Pravilnika o ravnanju z odpadki (UL RS 84/1998 z dopolnitvami) kot temeljnega predpisa o ravnanju z odpadki. Ta pravilnik imenujemo tudi »splošni pravilnik o odpadkih «, saj določa obvezna ravnanja z njimi in druge pogoje za njihovo zbiranje, prevažanje, predelavo in odstranjevanje. Pomemben je tudi zato, ker uvaja evropski klasifikacijski seznam vseh vrst odpadkov, med katerimi so posebej opredeljeni nevarni odpadki. Pravilnik poudarja, da morajo biti zbiranje, skladiščenje, prevoz, predelava in odstranjevanje odpadkov izvedeni tako, da ni ogroženo človekovo zdravje, in brez uporabe postopkov in metod, ki bi čezmerno obremenjevali okolje. 
Od leta 2000 je obvezna ravnanja z odpadki in druge pogoje za njihovo odlaganje ter delovanje odlagališč določal Pravilnik o odlaganju odpadkov (UL RS 5/2000 z dopolnitvami), ki ga je leta 2006 nasledila Uredba o odlaganju odpadkov na odlagališča (UL RS 32/2006). Posebej je poudarjeno, da je odpadke dovoljeno odlagati samo na odlagališčih. S tem je odpadke prepovedano odlagati na tistih mestih in območjih, ki niso opredeljena kot odlagališča. Navedeno je tudi, da odlagališče ne sme biti na vodovarstvenem območju.

Pravilnik o obremenjevanju tal z vnašanjem odpadkov (UL RS 3/2003) določa obvezna ravnanja pri načrtovanju in izvedbi zemeljskega izkopa ali umetno pripravljene zemljine zaradi izboljšanja ekološkega stanja tal, kar je pomembno za sanacijo gramoznic, tako praznih kot zapolnjenih z odpadki.

Glede na to, da področje ravnanja $z$ odpadki sodi pod resor Ministrstva za okolje in prostor, je največ pristojnosti dano Inšpektoratu RS za okolje in prostor, organu v sestavi tega ministrstva. Nekatera določila predpisov s tega področja nadzorujejo tudi tržni, zdravstveni in veterinarski inšpektorji ter inšpektorji za jedrsko varnost in energetiko, razen teh pa še mestni inšpektorji.

Varovanje voda določa in usmerja Okvirna direktiva o vodah, sprejeta leta 2000 v Evropskem parlamentu in v Svetu ministrov Evropske unije. Temelji na celovitem in trajnostnem gospodarjenju z vodami, pri čemer sta pomembni tako količina kot kakovost različnih tipov voda, tudi podzemnih (Lanz, Scheuer 2001). Krovni zakon s področja voda v Sloveniji je Zakon o vodah (UL RS 67/2002), ki je seveda usklajen z evropsko direktivo.

Varstveni pasovi virov pitne vode oziroma vodovarstvena območja, kot se imenujemo v zadnjem času, imajo na Ljubljanskem polju že dolgo tradicijo. Prvič so jih določili leta 1955. Bili so odločilni za varovanje vodnega vira, ker so omejili širitev mesta v bližino črpališč (Breznik 1988). V letih 1977 in 1988 sta sledila posodobljena odloka. Najnovejša Uredba o vodovarstvenem območju za vodno telo vodonosnika Ljubljanskega polja (UL RS 120/2004) temelji na obsežnem raziskovalnem delu. Je prva tovrstna uredba, ki izhaja iz Pravilnika o kriterijih za določitev vodovarstvenega območja (UL RS 64/2004).

Pogoje in način oskrbe s pitno vodo v Ljubljani ureja Odlok o oskrbi s pitno vodo (UL RS 17/2006). Pravilnik o pitni vodi (UL RS 19/2004 z dopolnitvami) postavlja zahteve za skladnost in zdravstveno ustreznost pitne vode in predpisuje pogoje za zagotavljanje zdrave pitne vode. Uredba o standardih kakovosti podzemne vode (UL RS 100/2005) navaja merila za določitev njenega kemijskega stanja, vrednotenje dolgoročnih trendov njene onesnaženosti in njihovih sprememb, stanje obremenjenosti vodnega telesa, ko je treba začeti izvajati ukrepe za preprečevanje in omejevanje vnosa onesnaževal v podzemno vodo, in merila za prenehanje izvajanja sanacijskih ukrepov.

\section{Metode dela}

Inventarizacija divjih odlagališč odpadkov, analiza njihovega stanja in priprava predlogov sanacije je od marca do septembra 2006 potekala v več delovnih fazah (Smrekar in ostali 2006):

- pripravljalna dela: analiza literature in sekundarnih virov, preučitev zakonskih aktov, zbiranje dostopnih obstoječih podatkovnih baz;

- terensko delo: kartiranje in popisovanje divjih odlagališč, zajemanje podatkov z dlančnikom;

- računalniška obdelava podatkov: vnašanje in organiziranje prostorskih podatkov v podatkovne baze, statistične obdelave, prostorske analize;

- kemijska analiza vzorcev: priprava in analiza reprezentativnih vzorcev;

- grafična predstavitev: prikaz rezultatov dejanskega stanja na zemljevidih in v grafikonih;

- sanacijski program: predlog najnujnejših sanacijskih posegov.

Slika 2: Terenski popis divjih odlagališč odpadkov.

Glej angleški del prispevka.

Določanje prednostne sanacije divjih odlagališč odpadkov je bilo izvedeno na podlagi kazalnikov, ključnih z vidika okoljske problematike (Breg in ostali 2005). Upoštevane so bile pokrajinskoekološke značilnosti območja z vidika obremenjevanja vodnega vira in nekatere popisane značilnosti odlagališča. Kazalnike smo združili v štiri vsebinske sklope in jim glede na njihov pomen z vidika določanja prioritete prednostne sanacije divjih odlagališč določili ponderje ali uteži. 


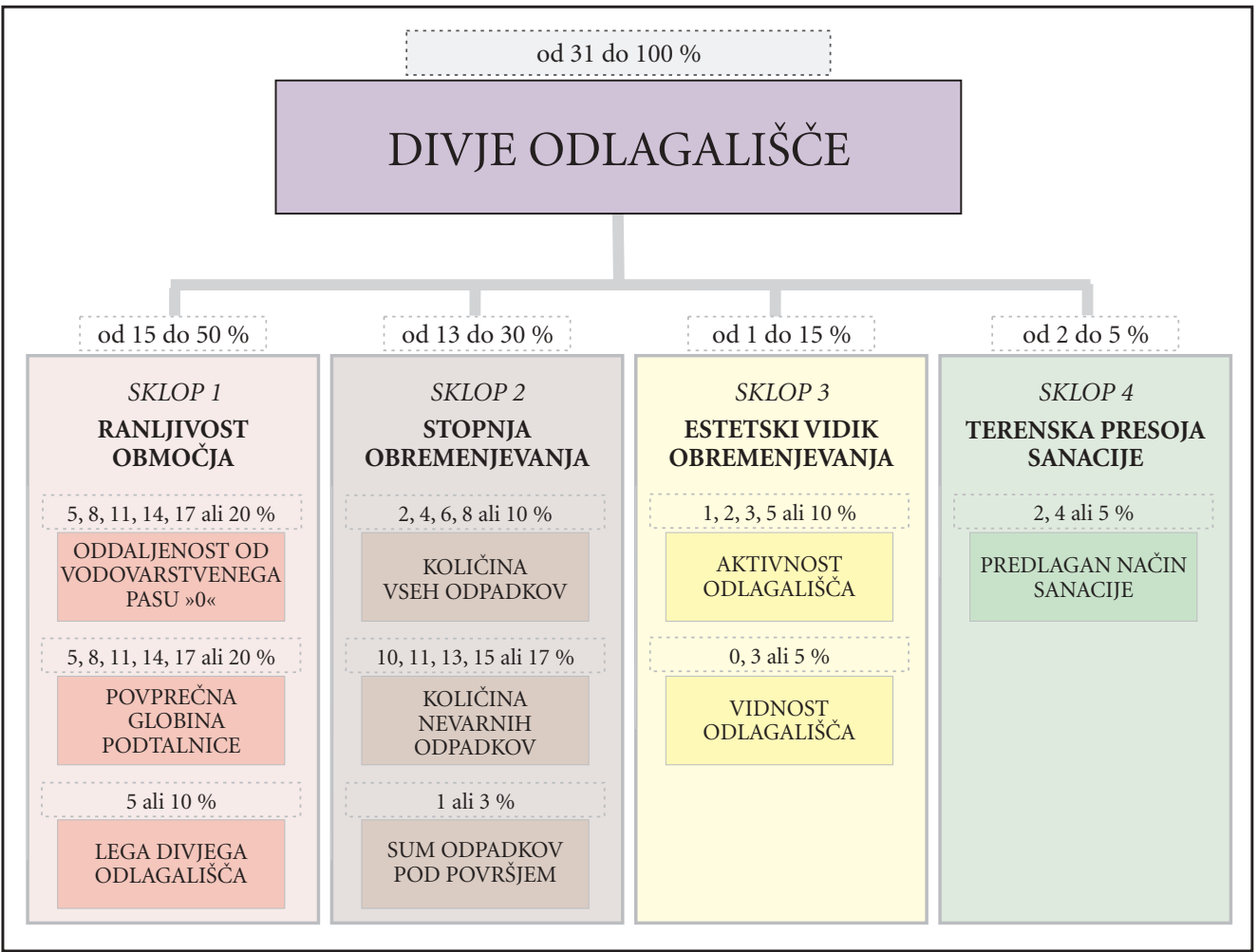

Slika 3: Klasifikacija in vrednotenje kazalnikov prednostne sanacije divjih odlagališč.

V članku uporabljamo izraz divje odlagališče odpadkov, katerega sopomenki sta izraza nedovoljeno odlagališče odpadkov in neurejeno odlagališče odpadkov. V literaturi se srečujemo še z izrazoma črno odlagališče in nelegalno odlagališče (Kladnik in ostali 2005).

\section{Temeljne značilnosti preučenih objektov}

Kataster odlagališč odpadkov je obstajal že prej. Podjetje Oikos je septembra 1996 pregledalo celotno območje Mestne občine Ljubljana (Kobal in ostali 1996). Evidentiralo je 457 odlagališč s skupno prostornino $32.782 \mathrm{~m}^{3}$. Prav tako je bila na ravni celotne občine opravljena študija podjetja Bion (Berden in ostali 2004), v kateri so bili podatki obdelani po četrtnih skupnostih. Preučenih je bilo 278 divjih odlagališč z ocenjeno skupno prostornino $100.000 \mathrm{~m}^{3}$. Pri vseh študijah je bila mejna vrednost evidentiranega odlagališča $1 \mathrm{~m}^{3}$ odpadkov. Zanimivo in nenavadno je, da naj bi se po navedenih podatkih število odlagališč med letoma 1996 in 2004 zmanjšalo za skoraj štiri desetine, količina odpadkov pa naj bi se povečala za več kot trikrat.

Že pred dobrim desetletjem je bila opravljena prva temeljita preučitev divjih odlagališč odpadkov v Sloveniji (Šebenik 1994). Pomembna novost Šebenikovega pristopa v primerjavi z dotedanjimi raziskavami je precej natančnejša obravnava količinskih parametrov odlagališč. Šebenik je analiziral 3501 vzorčno odlagališče v velikosti od 1 do $10.000 \mathrm{~m}^{3}$. Povprečno odlagališče je merilo $135 \mathrm{~m}^{2}$ in imelo $47 \mathrm{~m}^{3}$ odpadkov. $\mathrm{Na}$ do $1000 \mathrm{~m}^{3}$ velikih odlagališčih je bilo $39 \%$ odpadkov, kar pomeni, da so manjša odlagališča pomembna tudi z vidika količine odpadkov in ne le zaradi številčnosti.

Na obravnavanem območju smo našli, popisali in preučili kar 1445 divjih odlagališč odpadkov. Njihova skupna površina je $120.816 \mathrm{~m}^{2}$, kar pomeni, da je z odpadki prekrito $0,28 \%$ celotnega območja. Gre torej za eno z odpadki najbolj obremenjenih območij pri nas. Skupna prostornina odpadkov znaša $209.422 \mathrm{~m}^{3}$. 
Povprečno odlagališče meri $83,6 \mathrm{~m}^{2}$ in ima $145,5 \mathrm{~m}^{3}$ odpadnega materiala. Evidentirali smo še 86 gramoznic, 47 obvestilno-opozorilnih tabel in 57 ovir na dovoznih poteh.

$\mathrm{V}$ podjetju Snaga, ki je v Ljubljani zadolženo za odvažanje komunalnih odpadkov, so z vseh divjih odlagališč v Mestni občini Ljubljana v zadnjih šestih letih (2000-2005) po naročilu inšpekcijskih služb odpeljali skupno $36.499 \mathrm{~m}^{3}$ komunalnih odpadkov.

Slika 4: Popisani objekti.

Glej angleški del prispevka.

\subsection{Velikostni parametri odlagališč odpadkov}

Med popisanimi 1445 divjimi odlagališči odpadkov prevladujejo majhna odlagališča. Kar 550 oziroma dobra tretjina jih ne presega $10 \mathrm{~m}^{2}$, še največ ( 696 ali 48,1\%) pa jih je v velikostnem razredu od 11 do $100 \mathrm{~m}^{2}$. Le 199 odlagališč meri več kot $100 \mathrm{~m}^{2}$, samo 24 pa jih presega $1000 \mathrm{~m}^{2}$, vendar ta skupaj zavzemajo 7,3\% celotne površine odlagališč. Površino največjega odlagališča ocenjujemo na $6000 \mathrm{~m}^{2}$.

$Z$ večanjem površine odlagališč odpadkov se praviloma povečuje tudi njihova debelina. Čeprav kar 802 odlagališči ne presegata debeline $1,0 \mathrm{~m}$ (360 niti $0,5 \mathrm{~m}$ ), so odpadki na več kot stotih nakopičeni vsaj 2 metra na debelo, najbolj, celo $11 \mathrm{~m}$, v eni od opuščenih gramoznic.

Kar 757 ali več kot polovica (52,4\%) odlagališč prostorninsko ne presega $10 \mathrm{~m}^{3}$, vendar je na njih odložen le dober odstotek $(1,3 \%)$ celotne količine ugotovljenih odpadkov. Na drugi strani je 36 odlagališč s prostornino $1000 \mathrm{~m}^{3}$ in več, na katerih je nakopičenih skoraj tri četrtine $(72,5 \%)$ odpadkov. Največje odlagališče vsebuje okrog $42.000 \mathrm{~m}^{3}$ ali skoraj petino ugotovljenih odpadkov.

Manjši del odpadkov je na zemljiščih v zasebni lasti, večina pa je v kategoriji javno dobro oziroma na zemljiščih v lasti pravnih oseb. Na slednjih je 54,0 \% površine in $61,3 \%$ prostornine registriranih odpadkov. Vse to razkriva pomanjkljiv nadzor javnega sektorja, četudi so pred nedovoljenim odlaganjem očitno nemočni tudi zasebniki. Na občinskih zemljiščih je 16,5\% divjih odlagališč, ki zavzemajo več kot četrtino $(25,8 \%)$ vseh zasedenih površin oziroma več kot tretjino $(37,8 \%)$ celotne količine evidentiranih odpadkov.

Slika 5: Divja odlagališča odpadkov glede na sektor lastništva zemljišč.

Glej angleški del prispevka.

\subsection{Sestava odpadkov}

Nelegalno odloženi odpadki so le redko homogeni. Večinoma gre za mešanico odpadkov (gradbeni, industrijski, komunalni, odpadki iz primarnega sektorja, jalovina) lokalnega izvora.

Njihova lega je pogosto neugodna tako z vidika onesnaževanja podtalnice kot motečega videza, kar vpliva na kakovost bivalnega okolja in turistično-rekreacijsko privlačnost pokrajine.

$\mathrm{V}$ raziskavi smo odpadke razčlenili v naslednje skupine:

- odpadki primarnega sektorja;

- industrijski odpadki;

- gradbeni odpadki;

- zdravstveni in veterinarski odpadki;

- komunalni odpadki;

- drugi odpadki.

Podrobnejša členitev po vrstah odpadkov je razkrila, da sta dve tretjini $(67,3 \%)$ odpadkov gradbenega izvora (odpadki od rušenja objektov, odvečna zemljina iz izkopov za novogradnje), ki jim s 17,8 \% sledijo odpadki primarnega sektorja. Komunalnih odpadkov je 10,2\%, industrijskih 1,4\%, medtem ko je odpadkov iz zdravstvene in veterinarske dejavnosti 1,1\%.

Vpliv gradbenih odpadkov na okolje je na splošno zanemarljiv, vendar le, če odpadki ne vsebujejo sestavin, ki bi lahko kemično onesnažile okolje. Običajni gospodinjski odpadki navadno vsebujejo tudi nevarne kemične snovi v obliki motornih olj, pralnih sredstev, razpršilcev in podobnega (Šebenik 1994). Zaradi nevarnosti onesnaženja podtalnice morajo imeti pri predvideni sanaciji odlagališč prednost. 
Slika 6: Sestava in količina odpadkov na divjih odlagališcih.

Glej angleški del prispevka.

Nevarne odpadke sestavljajo večinoma odpadna osebna vozila, sodi z neznano vsebino (prazni kovinski sodi so sicer uvrščeni med kosovne odpadke) in embalaže barv, lakov, motornih olj ali agrokemičnih pripravkov. Komunalni odpadki so večinoma trdni, po sestavi heterogeni gospodinjski in njim podobni odpadki, ki nastajajo $\mathrm{v}$ proizvodnih in storitvenih dejavnostih, $\mathrm{v}$ bivalnem okolju ter na površinah in objektih $v$ javni rabi. Zaradi pestre in spremenljive sestave jih je tehnološko težko razstaviti na sestavine. Količina komunalnih odpadkov je po svoje presenetljiva, saj ima po podatkih Javnega podjetja Snaga d. o. o. iz Ljubljane urejen odvoz odpadkov $99 \%$ gospodinjstev.

Skupno je $28.749 \mathrm{~m}^{3}$ nevarnih odpadkov, kar predstavlja 13,7 \% celotne količine. Glavni nevarni gradbeni odpadki so salonitne plošče, asfalt, steklena volna in katran za izolacijo. Nevarne industrijske odpadke sestavljajo deli strojev in naprav, ostanki hladilnikov, industrijska lepila, embalaža od barve in topil, plastenke z barvo, motorno olje in razni kovinski sodi z neznano vsebino. Med komunalne nevarne odpadke lahko uvrstimo ostanke gospodinjskih in drugih delovnih aparatov, ki vsebujejo dele z okolju nevarnimi snovmi.

\subsection{Okoljski parametri odlagališč odpadkov}

Odpadki so raztreseni po vseh, razen ograjenih območjih zajema (vodovarstveno območje 0). Največje število odlagališč ( 760 oziroma $52,6 \%$ od vseh s skupno površino $57.340 \mathrm{~m}^{2}$ oziroma $47,5 \%$ in prostornino $118.975 \mathrm{~m}^{3}$ oziroma $56,8 \%$ ) je na ožjem območju s strogim vodovarstvenim režimom (vodovarstveno območje IIA). Seveda so potencialno bolj nevarna odlagališča, ki so bliže vodarn (vodovarstveno območje I), vendar je tam količina odpadkov bistveno manjša. Na srečo je takšnih samo 71 s skupno površino $8589 \mathrm{~m}^{2}(7,2 \%)$ in prostornino $10.249 \mathrm{~m}^{3}(4,9 \%)$. Preostalih 831 odlagališč je na ožjem območju z manj strogim režimom (vodovarstveno območje IIB).

\section{Slika 7: Globina podtalnice pod divjimi odlagališči odpadkov.}

Glej angleški del prispevka.

Največ divjih odlagališč je v poraščenem, očem skritem okolju. V grmiščih, redkem in strnjenem gozdu je več kot polovica odlagališč s 46,0 \% površinskim in 39,6 \% prostorninskim deležem. Na neporaslem površju je »samo« 216 divjih odlagališčih. Nekaj odpadkov je tudi na neporaslih svežih prodiščih. 79 divjih odlagališč s prostornino $1092 \mathrm{~m}^{3}$ oziroma $0,5 \%$ od vseh odpadkov smo evidentirali celo na pozidanih zemljiščih.

126 divjih odlagališčih je v gramoznicah, kjer je odloženih kar 61,2 \% popisanih odpadkov s prostornino $128.150 \mathrm{~m}^{3}$, ki prekrivajo $55.873 \mathrm{~m}^{2}$ ali 46,2 \% od skupne površine odlagališč. Na Ljubljanskem polju smo evidentirali 87 gramoznic, med njimi je le 15 praznih. Gramoznice so se začele v večjem obsegu pojavljati po letu 1958 (Smrekar in ostali 2005).

Slika 8: Divje odlagališče odpadkov v gramoznici pri vrtičkarskem naselju.

Glej angleški del prispevka.

Glede na količino odpadkov z več kot polovičnim deležem (51,4\%) prednjačijo neaktivna odlagališča, polno aktivna pa prispevajo malo manj kot tretjino (30,9\%). Za kar 359 odlagališč $(24,8 \%)$ obstoji utemeljen sum, da se pod pregledanim površjem skrivajo dodatne količine odpadkov. Žal je ta sum prisoten zlasti pri večjih odlagališčih, na katerih smo evidentirali $87.009 \mathrm{~m}^{3}$ oziroma $41,5 \%$ od celotne količine odpadkov.

\section{Slika 9: Aktivnost divjih odlagališč odpadkov.}

Glej angleški del prispevka.

Divja odlagališča odpadkov so večinoma odmaknjena od naselij in pomembnejših prometnih poti. Eden od najpomembnejših dejavnikov za njihov nastanek je dostopnost mesta, kjer se lahko odložijo odpad- 
ki. Ta je na prodni ravnini praviloma lahka. Zato ne preseneča, da sta več kot dve tretjini divjih odlagališč $(67,5 \%)$ oddaljeni manj kot 5 metrov od dovoznih poti.

Do njih vodijo različne vrste poti. Največja prepreka za nemoten dovoz odpadnega materiala naj bi bile različne ovire, ki so postavljene tako na asfaltnih in makadamskih poteh kot na kolovozih in stezah. Žal jih je v mnogih primerih mogoče zaobiti. Zanimivo je, da je 222 odlagališč z 42,9\% skupne površine in 55,0 \% skupne prostornine dostopnih le prek ovir, kar kaže, da skušajo pristojne službe nenadzorovano odlaganje odpadkov omejevati. Žal se pred zaporami kopičijo novi kupi odpadkov.

Slika 10: Dostopnost divjih odlagališč odpadkov glede na njihovo površino $\left(\mathrm{m}^{2}\right)$ in prostornino $\left(\mathrm{m}^{3}\right)$.

Glej angleški del prispevka.

Večina od evidentiranih 57 ovir je osredotočenih vzdolž obeh bregov Save, še zlasti dolvodno od Broda na desnem bregu in Črnuč na levem bregu reke. Najpogostejše so zapornice in nasipi. Marsikje je kot ovira odložen manjši ali večji kup odpadkov na makadamski cesti (gradbeni material, avtomobilske gume, kup kamenja ipd.), zlasti v gozdu na Jarškem produ so za ta namen podrta drevesa. Ponekod so izkopani jarki, vendar je takšne ovire mogoče zasuti z odpadnim materialom, naleteli pa smo tudi na betonske piramide. 159 odlagališč $(11,0 \%)$ je ograjenih. Več deset je tudi (malo učinkovitih) tabel s prepovedjo odlaganja ali kakšnim podobnim opozorilom.

Problem neželenega onesnaževanja naravnega okolja bi lahko rešila le trajnejša ureditev prizadetih območij z rednim nadzorom, kaznovalno politiko in njihovim čiščenjem. Nujno je tudi ozaveščanje potencialnih onesnaževalcev. Izobraževalno naj bi delovalo zlasti informiranje in ljudi opominjalo na prepoved odlaganja. Nadzor inšpekcije in policije bi bilo potrebno poostriti in kaznovati tiste, ki sporočil ne spoštujejo in zaobidejo postavljene ovire. Postavitev zapornic na dostopnih poteh naj bi bilo zadnje v nizu opozoril, da se na določenem območju odpadki nikakor ne smejo več odlagati.

\section{Prednostna sanacija odlagališč odpadkov}

Stroški za občasno sanacijo večjih odlagališč so dolgoročno večji od rednega odvoza materiala z manjših odlagališč, kar pa velja le, ko je takšen sistem vzpostavljen (Berden Zrimec in ostali 2004). Zato je nedopustno, da na saniranih lokacijah prihaja do ponovnega odlaganja.

Sčasoma bo treba sanirati vsa divja odlagališča odpadkov, vendar je zaradi velike količine odpadkov nerealno pričakovati, da bi to lahko naredili naenkrat. Zato smo na podlagi ocen štirih vsebinskih sklopov določili prednostni vrstni reda sanacije.

Zaradi velike teže, ki jo ima sklop ranljivost območja, saj prispeva kar polovico vseh možnih točk, ni presenetljivo, da je 58 divjih odlagališč v prvem prednostnem razredu z od 71 do 93 točkami (od teoretično možnih 100) na večini obravnavanih območij v bližini vodarn. Zlasti značilna so za okolico vodarne Jarški prod. Nekatera so sicer že dolvodno od vodarn, vendar zaradi izdatnega črpanja pitne vode nastajajo depresijski lijaki, kar pomeni, da so še vedno v njihovih prispevnih območjih. Nekaj najbolj obremenjujočih divjih odlagališč odpadkov je v nekdanjih gramoznicah, kjer je do gladine podtalnice le majhna razdalja.

218 divjih odlagališč odpadkov ( $15,1 \%$ od vseh) dosega od 61 do 70 točk in so uvrščena v drugi prednostni razred. Na Ljubljanskem polju so zgoščena zlasti na štirih območjih, še največ pa jih je na Jarškem produ. Večje zgostitve so še na desnem bregu Save med Jaršami in Sneberjami, severno od Kleč in jugozahodno od Hrastja. Precej jih je v nekdanjih gramoznicah.

Tretji prednostni razred z od 51 do 60 točkami, v katerega je uvrščenih 491 (34,0\%) divjih odlagališč odpadkov, je brez posebnih zakonitosti razpršen po vseh preučevanih območjih.

V četrti razred, ki dosega od 41 do 50 točk, je uvrščenih 493 (34,1\%) divjih odlagališč. Tudi ta so dokaj enakomerno razporejena, vendar je opazno, da jih je manj v bližinah vodarn, še zlasti na območjih Jarškega proda in Hrastja.

V peti razred z manj kot 40 točkami (najmanjše število je 26) je uvrščenih 183 divjih odlagališč. Ker praviloma niso v okolici vodarn in njihovi odpadki niso pretirano škodljivi, je potreba po njihovi sanaciji najmanjša.

Slika 11: Prednostna sanacija divjih odlagališč odpadkov.

Glej angleški del prispevka. 


\section{Sklep}

Primerjava med različnimi popisi na območju celotne Mestne občine Ljubljana ali v njenih posameznih delih kljub enotnemu kriteriju evidentiranja odlagališč z vsaj $1 \mathrm{~m}^{3}$ odpadki kaže na precejšnja neujemanja. V preglednici je prikazana primerjava rezultatov popisov iz let 1996 (podjetje Oikos d. o. o.), 2000 (diplomska naloga Simona Kušarja, ki zajema le odprt svet Ljubljanskega polja), 2004 (Inštitut za bioelektromagnetiko in novo biologijo) in 2006 (Geografski inštitut Antona Melika ZRC SAZU).

Preglednica 1: Primerjava rezultatov različnih popisov divjih odlagališč odpadkov v Mestni občini Ljubljana.

\begin{tabular}{llcccc}
\hline $\begin{array}{l}\text { leto } \\
\text { popisa }\end{array}$ & območje zajema & $\begin{array}{c}\text { površinaštevilo popisanih } \\
\left(\mathrm{km}^{2}\right)\end{array}$ & $\begin{array}{c}\text { ocenjena } \\
\text { odlagališč }\end{array}$ & $\begin{array}{c}\text { ocenjena } \\
\text { površina }\left(\mathrm{m}^{2}\right)\end{array}$ & $\begin{array}{c}\text { prostornina } \\
\left(\mathrm{m}^{3}\right)\end{array}$ \\
\hline 1996 & Mestna občina Ljubljana & 275,0 & 457 & 70.448 & 32.761 \\
2000 & odprt svet Ljubljanskega polja & neznano & 359 & 163.400 & 84.000 \\
2004 & Mestna občina Ljubljana & 275,0 & 278 & neznano & 100.000 \\
2006 & del vodovarstvenih območij & 45,8 & 1482 & 122.573 & 211.279 \\
& v Mestni občini Ljubljana & & & & \\
\hline
\end{tabular}

K tako velikim razlikam je verjetno pripomoglo več dejavnikov: različna natančnost zajema, subjektivnost popisovalcev in letni čas zajema (v zimskem času brez snežne odeje je vidnost bistveno večja).

Reševanje problema divjih odlagališč odpadkov bi moralo potekati na dveh ravneh. Na prvi je nujna sanacija obstoječih odlagališč in s tem odstranitev točkovnih in pri večjih ploskovnih virov obremenjevanja podzemne vode, na drugi, sočasni, pa je potrebno učinkovito preprečevanje nastajanja novih odlagališč in strogo sankcioniranje morebitnih kršiteljev, pri čemer bi bile nujne tudi akcije za dvig okoljske zavesti.

Doslej primerne volje in posledično sredstev za reševanje neugodnega stanja ni bilo dovolj. V zadnjem času je mestna oblast očitno spoznala nujnost ukrepanja, na kar kaže dejstvo, da poleg odvažanja, ki ga je že v preteklosti izvajala Snaga, izvaja tudi prve celovitejše korake. Tako se za najbolj obremenjeno območje Jarški prod pripravlja sanacijski projekt, ki mu bo sledila pilotna izvedba sanacije.

S Prostorskim planom Mestne občine Ljubljana (2002) je preučeno območje predvideno kot območje gozdov s poudarjenim ekološkim ali rekreacijskim pomenom. Vzdolž Save bi lahko uredili sistem sprehajalnih in kolesarskih poti, kar bi prostoru ob ustrezni sanaciji dalo povsem nove kakovostne razsežnosti. Tu so tudi idealne možnosti za postavitev vodne učne poti, saj bi lahko primerno predstavili raznovrstne vsebine, kot na primer črpališče pitne vode, suho strugo nekdanjega rečnega toka, regulacije rečnega korita, gramoznico s profilom krovne plasti in proda na aluvialni ravnini kot neprimernega gradbenega materiala, divje odlagališče odpadkov kot način neustrezne sanacije gramoznice tik nad gladino podtalnice ipd.

Za uspešno udejanjanje ciljev ravnanja z odpadki so potrebni informiranje, izobraževanje in ozaveščanje. Prizadevanja brez podpore in primerne okoljske ozaveščenosti lokalnega prebivalstva zagotovo ne bodo dosegla cilja, to je urejene in zdrave domače pokrajine. Ljudje morajo spremeniti življenjski slog, tako da bodo prostorske vrednote postale njegov sestavni del. Neproblematično okolje mnogim očitno še ne pomeni vrednote. Na preučenem območju je za zdaj takšnih manj kot četrtina (Smrekar 2006). Obveščanje, izobraževanje in osveščanje posameznikov in družbenih skupin je zagotovilo za oblikovanje zrelega in odgovornega odnosa do prostora, v katerem živimo (Urbanc, Fridl 2007). Slednje mora postati vrednota, ki bo zasedala visoko mesto na vrednostni letvici ljudi. Za običajnega človeka je vrednota pojem o temeljnih kategorijah želenega, dobrega, pozitivnega (Urbanc 2006), ali kot pravi Slovar slovenskega knjižnega jezika (1995), da je namreč vrednota tisto, čemur kdo priznava veliko načelno vrednost in mu zato daje prednost.

Ta in druga prizadevanja na ravni Mestne občine Ljubljana izvaja zlasti Zavod za varstvo okolja. Njegovo poslanstvo je tudi izdajanje informativno-motivacijskih publikacij, kakršni sta na primer Okolje v Mestni občini Ljubljana (2004) in Vodnik o varovanju podzemne vode v Mestni občini Ljubljana (2005).

Slika 12: Ozaveščanje najmlajših je korak k ohranitvi okolja in premišljenemu odnosu do prostora.

Glej angleški del prispevka.

Članek je rezultat raziskovalnega projekta Odlagališča odpadkov na vodovarstvenem območju, pomembnem za oskrbo Mestne občine Ljubljana s pitno vodo, ki smo ga pripravili na Geografskem inšti- 
tutu Antona Melika Znanstvenoraziskovalnega centra Slovenske akademije znanosti in umetnosti s podizvajalcema Javnim podjetjem Vodovod-Kanalizacija d. o. o. in Kemijskim inštitutom. Za financiranje se zahvaljujemo Oddelku za kulturo in raziskovalno dejavnost Mestne občine Ljubljana ter Javnemu podjetju Vodovod-Kanalizacija d. o. o.

\section{Literatura}

Glej angleški del prispevka. 